\title{
Antibacterial Peptide Nucleic Acids-Facts and Perspectives
}

\author{
Monika Wojciechowska ${ }^{1, *}$, Marcin Równicki ${ }^{1,2}$, Adam Mieczkowski ${ }^{3}{ }^{\circledR}$, Joanna Miszkiewicz ${ }^{1,2}$ \\ and Joanna Trylska ${ }^{1, * \mathbb{D}}$ \\ 1 Centre of New Technologies, University of Warsaw, Banacha 2c, 02-097 Warsaw, Poland; \\ m.rownicki@cent.uw.edu.pl (M.R.); j.miszkiewicz@cent.uw.edu.pl (J.M.) \\ 2 College of Inter-Faculty Individual Studies in Mathematics and Natural Sciences, University of Warsaw, \\ Banacha 2c, 02-097 Warsaw, Poland \\ 3 Institute of Biochemistry and Biophysics, Polish Academy of Sciences, Pawińskiego 5a, 02-106 Warsaw, \\ Poland; amiecz@ibb.waw.pl \\ * Correspondence: m.wojciechowska@cent.uw.edu.pl (M.W.); joanna@cent.uw.edu.pl (J.T.)
}

Academic Editor: Eylon Yavin

Received: 28 December 2019; Accepted: 22 January 2020; Published: 28 January 2020

\begin{abstract}
Antibiotic resistance is an escalating, worldwide problem. Due to excessive use of antibiotics, multidrug-resistant bacteria have become a serious threat and a major global healthcare problem of the 21st century. This fact creates an urgent need for new and effective antimicrobials. The common strategies for antibiotic discovery are based on either modifying existing antibiotics or screening compound libraries, but these strategies have not been successful in recent decades. An alternative approach could be to use gene-specific oligonucleotides, such as peptide nucleic acid (PNA) oligomers, that can specifically target any single pathogen. This approach broadens the range of potential targets to any gene with a known sequence in any bacterium, and could significantly reduce the time required to discover new antimicrobials or their redesign, if resistance arises. We review the potential of PNA as an antibacterial molecule. First, we describe the physicochemical properties of PNA and modifications of the PNA backbone and nucleobases. Second, we review the carriers used to transport PNA to bacterial cells. Furthermore, we discuss the PNA targets in antibacterial studies focusing on antisense PNA targeting bacterial mRNA and rRNA.
\end{abstract}

Keywords: oligonucleotides; peptide nucleic acid (PNA); antibacterials; RNA; PNA transporters; conjugates; bacterial resistance

\section{Introduction}

Excessive use of antibiotics has led to an alarming situation when many bacterial strains developed resistance to these antibiotics. According to the World Health Organization, resistance to existing antibiotics, and slow rate of developing their new classes are currently among the greatest threats for human health $[1,2]$. Bacteria are particularly dangerous because they have already acquired resistance to several antibiotics at once, which has led to multi-drug resistance strains (MDR). The MDR among clinical isolates have made the current antibiotics inefficient, which, in turn, has increased the spread of resistant bacteria [3]. In the light of these facts, development of new potent antimicrobial agents is extremely necessary [4]. Long development times and high costs limit the discovery of new antimicrobial agents, so the most effective antibiotics are based on modifications of the previously discovered ones [5]. Thus, we urgently need new antibiotic types with a new mechanism of action.

Antisense oligonucleotides, used to inhibit the synthesis of proteins essential for bacteria to sustain life, may be helpful in the fight against bacterial infections. One such oligonucleotide is the peptide nucleic acid (PNA) molecule that combines the properties of both peptides and nucleic acids. PNA 
were designed as synthetic analogues of DNA [6], which contain a neutral backbone, are resistant to enzymes degrading proteins [7] and nucleic acids [8] and form stable complexes with DNA and RNA. PNA oligomers are synthesized on solid support with a simple method similar to that used to synthesize peptides. This method, known as solid-phase peptide synthesis (SPPS), has been well described in the literature [9].

Inside bacteria, antisense PNA oligomers inhibit the translation process by binding to mRNA or the ribosome. The antisense effect of PNA is based on the formation of hydrogen bonds between the complementary PNA sequence and selected nucleic acid target. An important advantage of PNA is its selectivity and high-affinity binding. Thanks to that, it is possible to design PNA-based antimicrobials specific for particular genes in selected bacteria. In principle, PNA show huge potential to control the spread of resistant microorganisms. Unfortunately, the use of PNA in antibacterial applications encountered several crucial obstacles. The hydrophobicity of the PNA backbone causes problems with PNA solubility in aqueous solutions, which leads to PNA adopting compact structures susceptible to aggregation [10]. One of the consequences of PNA poor water solubility is difficulty in the delivery of PNA oligonucleotides to bacterial cells [11]. Several strategies of improving the PNA solubility in water and increasing PNA uptake by bacteria have been proposed $[12,13]$. In this review, we have summarized and presented these strategies. In the last decade, a few reviews on PNA antibacterial applications have been published, e.g., [14-18]. We have updated this information, specifically focusing on PNA modifications, structural data for PNA-involving complexes, antibacterial targets, and transport into bacterial cells.

\section{PNA Complexes with Natural Nucleic Acids}

To point-out the antibacterial potential of PNA and challenges facing any future therapeutic applications of these molecules, it is necessary to understand the structural and physicochemical properties of PNA. In this section, we present the most relevant PNA properties and structural fundaments of PNA complexes with nucleic acids.

Besides the higher enzymatic stability, PNA has another important advantage: it hybridizes with complementary sequences of natural nucleic acids creating either duplexes or triplexes. So far, nearly 20 structures containing PNA oligomers have been solved by X-ray crystallography or nuclear magnetic resonance (NMR) including single-stranded PNA, PNA-PNA, PNA-DNA and PNA-RNA duplexes, and a triplex of double-stranded PNA with DNA (summarized in Table 1).

Table 1. Structures containing PNA available in the Protein Data Bank [19] (http://www.rcsb.org).

\begin{tabular}{|c|c|c|c|c|c|c|}
\hline Molecule & Structure & Method & Resolution & $\begin{array}{c}\text { Includes Modified PNA } \\
\text { Monomers }\end{array}$ & PDB ID & Ref. \\
\hline \multirow{10}{*}{ PNA-PNA } & duplex & X-ray & $1.82 \AA$ & bicyclic thymine analogue & $1 \mathrm{HZS}$ & [20] \\
\hline & duplex & NMR & - & - & $2 \mathrm{~K} 4 \mathrm{G}$ & [21] \\
\hline & duplex & X-ray & $1.70 \AA$ & - & 1PUP & [22] \\
\hline & duplex & X-ray & $2.35 \AA$ & - & 1RRU & [23] \\
\hline & duplex/triplex & X-ray & $2.60 \AA$ & - & 1XJ9 & [24] \\
\hline & duplex & NMR & - & $\gamma$-modified PNA & $2 \mathrm{KVJ}$ & [25] \\
\hline & duplex & X-ray & $1.27 \AA$ & - & 3MBS & [26] \\
\hline & duplex & X-ray & $2.20 \AA$ & N-methylated PNA backbone & 1QPY & [27] \\
\hline & duplex & X-ray & $1.05 \AA$ & bipyridine-modified PNA & $3 \mathrm{MBU}$ & [26] \\
\hline & duplex & X-ray & $1.06 \AA$ & contains T-T mismatches & 5EMG & [28] \\
\hline PNA & $\begin{array}{l}\text { single-stranded } \\
\text { PNA }\end{array}$ & X-ray & $1.00 \AA$ & D-alanyl and L-homoalanyl PNA & $3 \mathrm{C} 1 \mathrm{P}$ & [29] \\
\hline
\end{tabular}


Table 1. Cont.

\begin{tabular}{ccccccc}
\hline \multirow{2}{*}{ Molecule } & Structure & Method & Resolution & $\begin{array}{c}\text { Includes Modified PNA } \\
\text { Monomers }\end{array}$ & PDB ID & Ref. \\
\hline \multirow{3}{*}{ PNA-RNA } & duplex & NMR & - & - & $176 \mathrm{D}$ & {$[30]$} \\
\cline { 2 - 7 } & duplex & X-ray & $1.15 \AA$ & - & 5 EME & {$[28]$} \\
\cline { 2 - 7 } & duplex & X-ray & $1.14 \AA$ & - & $5 E M F$ & {$[28]$} \\
\hline \multirow{2}{*}{ PNA-DNA } & duplex & NMR & - & - & 1 PDT & {$[31]$} \\
\cline { 2 - 7 } & duplex & X-ray & $1.66 \AA$ & D-Lys based PNA & 1 1NR8 & {$[32]$} \\
\hline \multirow{nyyyyyy}{*}{ PNA-DNA-PNA } & duplex & X-ray & $1.60 \AA$ & $\gamma$-modified PNA & $3 P A 0$ & {$[33]$} \\
\hline
\end{tabular}

The simplest duplexes observing the Watson-Crick base-pairing scheme are formed by single-stranded PNA with complementary strands of DNA [31-33], RNA [28,30], or PNA [20-28] (Table 1). In these structures the single-strand of PNA (6-11 monomers), typically of a mixed sequence, binds to DNA or RNA strands in an antiparallel way $\left(C_{\text {term }}\right.$-PNA to $5^{\prime}$-DNA/RNA, N term-PNA to $3^{\prime}$-DNA/RNA). In most crystallized duplexes, the PNA terminus is extended with a lysine.

However, in general, classical PNA duplexes can be formed both in a parallel and antiparallel manner. Also, such PNA duplexes can form right- and left-handed P-type helices, characterized by a deeper and wider major groove, smaller angle, and larger displacement as compared to typical DNA and RNA helices. The P-type helix is $28 \AA$ wide and, for comparison, classical helices composed of natural oligonucleotides are $23 \AA$ (in the case of an A-helix) and $20 \AA$ (B-helix) wide. The P-type helix has 18 base pairs per turn (as compared to A-helix - 11 and B-helix - 10). The PNA-DNA or PNA-RNA hybrids tend to be organized as B- or A-like helices, respectively [23,34].

In addition to forming duplexes, single-stranded PNA can also bind to double-stranded DNA or RNA. Homopyrimidine PNA has the ability to bind a homopurine strand of a DNA duplex, opening the DNA helix and displacing the non-complementary DNA strand that forms the so-called P-loop [35]. As a result, a stable and thermodynamically favorable triplex-invasion complex is acquired (Figure 1a) [36]. If homopyrimidine PNA is rich in cytosines, it binds a DNA duplex without strand-displacement forming a classical triplex (Figure 1b). Notably, classical triplex can be also formed by binding a single strand of DNA to a PNA duplex. One such triplex has been crystallized by Betts et al. [34]; a homopurine DNA strand created a triplex with a homopyrimidine PNA hairpin (Table 1). The ability of PNA to create triplexes enables the formation of the so-called bis-PNA (a double-stranded PNA formed via e.g., an ethylene glycol type linker) [37,38] with two strands of DNA creating a tail clamp structure (Figure 1c). If PNA is a homopurine strand, a duplex invasion complex (Figure 1d) with a DNA duplex is created [39]. Moreover, under special circumstances, pseudo-complementary PNA strands with modified nucleobases-e.g., diaminopurine, thiothymine, and thiouracil-do not recognize each other due to steric hindrance and bind simultaneously to a double-stranded DNA forming a double duplex invasion complex (Figure 1e) [40,41]. In conclusion, five different modes of binding of PNA to double-stranded DNA have been found showing a wide and diverse capability of PNA to form complexes (Figure 1) [35].

Apart from NMR and crystallography, the complexes with PNA have been investigated also by other experimental methods, e.g., isothermal titration calorimetry [42,43], differential scanning calorimetry (DSC) [44], circular dichroism (CD) spectroscopy [45,46], UV-monitored thermal melting [44,45,47], fluorescence spectroscopy [46,47], gel electrophoresis [48,49], and nano-electrospray ionization mass spectrometry [46]. Computational methods, such as molecular dynamics simulations of single-stranded PNA [50-52] and of PNA-involving complexes [45,53-55] have been also performed giving insight into PNA (thermo)dynamics at atomistic level of detail. 


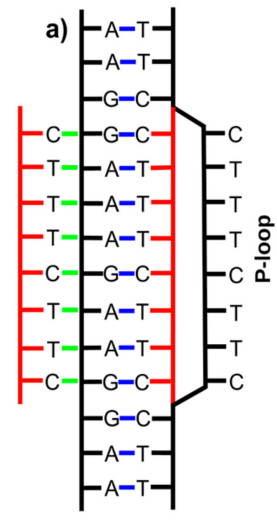

Triplex invasion

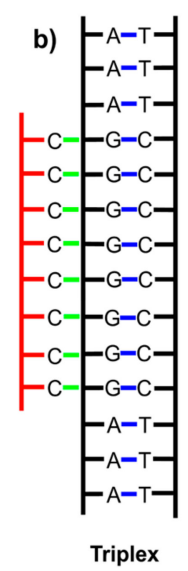

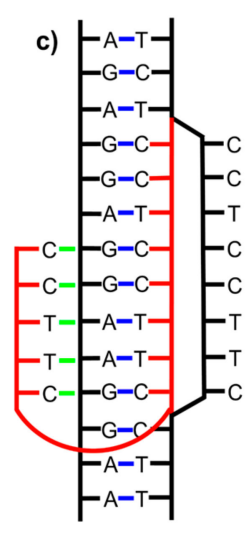

Tail clamp

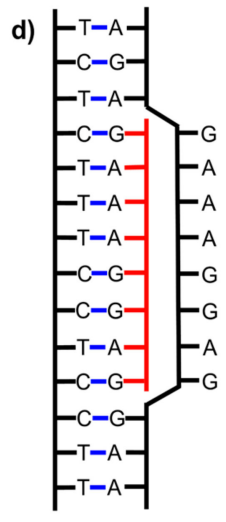

Duplex invasion

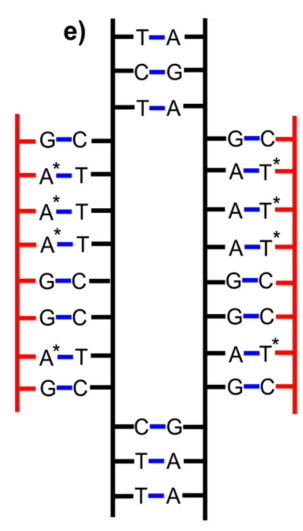

Double duplex invasion

Figure 1. Scheme showing the examples of complexes of PNA with double-stranded DNA: (a) triplex invasion, (b) triplex, (c) tail clamp, (d) duplex invasion, (e) double duplex invasion. Red lines -PNA backbone; black lines-DNA; blue dashed lines-Watson-Crick hydrogen bonds; green dashed lines-Hoogsteen-type hydrogen bonds; *-modified nucleotide bases [35].

PNA are achiral molecules, but chiral centers can be introduced by adding amino acids into the PNA oligomer or at its terminus (typically a lysine is added). As a result, CD can be observed confirming the helicity of PNA-PNA, PNA-DNA, and PNA-RNA duplexes [56].

Using UV spectroscopy complemented with molecular dynamics simulations, the melting temperature $\left(\mathrm{T}_{\mathrm{m}}\right)$ profiles of PNA-PNA and PNA-RNA 10-mer mixed-sequence duplexes were determined (Figure 2) [45]. The results showed that $\mathrm{T}_{\mathrm{m}}$ of the PNA-PNA duplex is higher than that of PNA-RNA by about 1.5 degrees per base pair. Molecular dynamics simulations of melting at atomistic level of detail suggested that a PNA duplex 'melts' cooperatively over its entire length, while PNA-RNA preferentially melts starting from the termini.
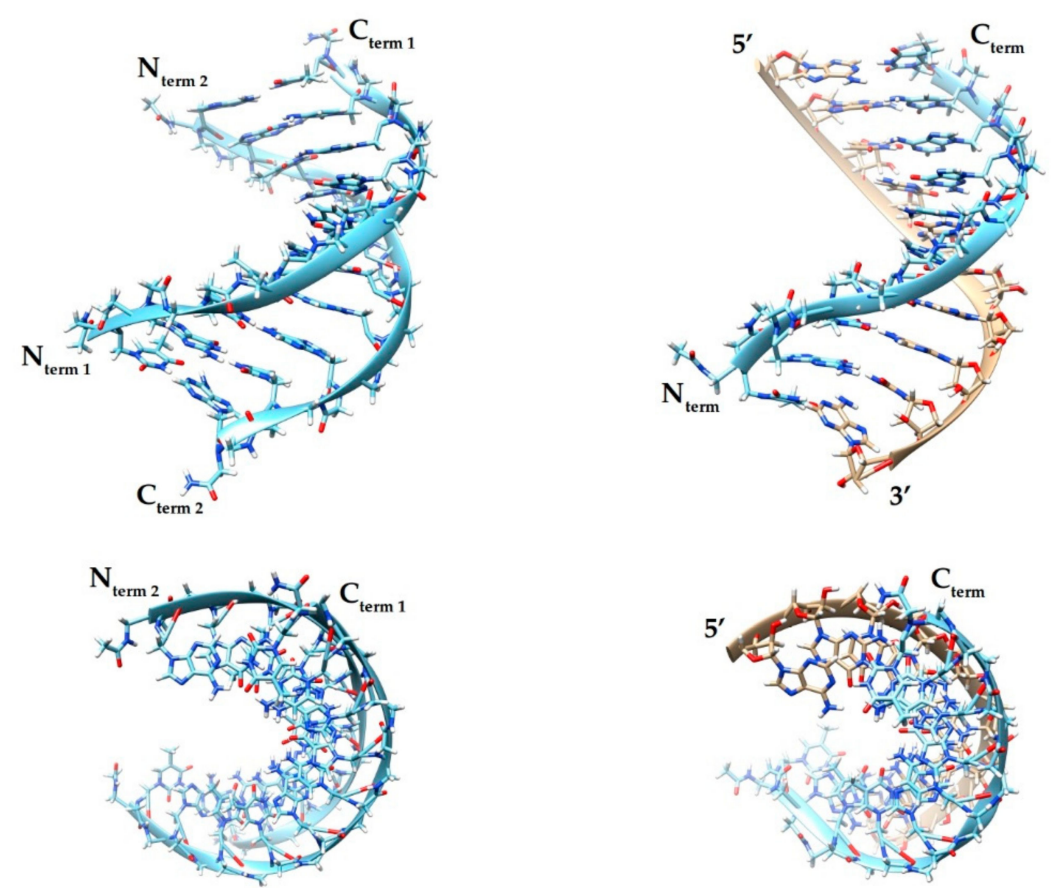

Figure 2. Side and top views of a PNA-PNA (left) and PNA-RNA (right) tertiary structures from molecular dynamics simulations [45]. The figure was made using Chimera 1.12 [57]. Light blue-PNA strands; beige—RNA; dark blue—nitrogen; red—oxygen; white—hydrogen. 
The types of complexes presented in Figure 1 depend not only on the sequence composition of the nucleic acid strands but also on many other factors such as the sequence length, the number of mismatches, the modifications introduced to PNA, environmental conditions such as buffer composition and ion concentration. Considering all these factors upon designing a PNA sequence for a particular application is not straightforward because our knowledge is limited. Thus, despite the large amount of work already put into the studies of PNA complexes with natural nucleic acids, many questions still remain unanswered and predictions of PNA binding affinities, especially to more complex RNA tertiary structures, are not evident.

\section{Chemical Modifications of PNA}

To improve PNA solubility or affinity toward natural nucleic acids, PNA peptide-like backbone has been further modified. Many structural modifications were introduced to change the properties of the PNA scaffold (1, see Figure 3 for numbering of scaffolds) including variations in length, type and functionalization of the peptide-like backbone, the type and length of the linker connecting the heterocyclic base to the backbone, as well as the type and functionalization of heterocyclic moieties. Modifications of the $N$-(2-aminoethyl)glycine backbone in the $\alpha-, \beta$ - or $\gamma$-position (Figure 3) result in a new stereogenic center, thus chiral PNA are formed [58]. Modifications introduced in the $\gamma$-position of the PNA backbone improved hybridization properties as compared to those introduced in the $\alpha$-position (Figure 3) [13].

The substituents incorporated into the PNA monomer backbone can be anionic, through introduction of the carboxylic 2, 3 [59], sulphate 4 group [60] or cationic 5, 6, 7. The cationic $\alpha$-aminomethylene 5 [61], $\alpha$-lysine 6 or guanidine 7 [62] in the PNA backbone enhanced cellular uptake and increased the stability of nucleic acid duplexes involving PNA. Furthermore, neutral moieties were also introduced including $\alpha$-methyl 8 [63], $\gamma$-methylthiol 9 [64], or $\gamma$-diethyleneglycol—"miniPEG" 10 [65] to modulate other PNA properties such as aggregation propensity, water solubility, sequence selectivity, and nucleic acid affinity. Preorganization of the PNA structure was achieved by introducing cyclic rigid moieties possessing carbocyclic cyclopentyl 11 [66], cyclohexyl 12 [67], or heterocyclic pyrrolidine scaffolds 13 [68,69]. Additionally, by introducing a linker between the heterocyclic group and peptide backbone, rigid, heterocyclic scaffolds based on pyrrolidine ring 14 [70,71] and 15 [72] as well as piperidine 16 [73] ring were developed. Finally, phosphono PNA, bearing phosphonoamidate bonds were synthesized from the appropriate phosphonate unit 17 [74].

To further modulate the properties of PNA oligomers [75], different nucleobase modifications were also developed, including modifications of functional groups in purine/pyrimidine bases and modifications of the heterocyclic core itself (Figure 4). Modified bases in the PNA monomers increased PNA affinity and selectivity, enhanced duplex stability and recognition, as well as triplex formation. In many cases, they also enabled monitoring PNA fluorescence.

The most common non-coding pyrimidine bases introduced in PNA include 2-thiouracil 18, used for the development of pseudo-complementary PNA [76,77], pseudoisocytosine 19 [78], thio-pseudoisocytosine 20 [49], and 2-aminopyrimidine 21 [79] for stable triplex formation with RNA duplexes. $N^{4}$-benzoylcytosine 22 was introduced by the Nielsen group [80,81] as a candidate for a pseudo-complementary G-C base pair, and 5-(acridin-9-ylamino)uracil 23 was applied as fluorescent, hydrolytically labile nucleobase modification [82]. Manicardi et al. studied the pyrene-labeled, fluorescent PNA monomer 24 [83] and used it to investigate stacking interactions and selective excimer emission in $\mathrm{PNA}_{2} / \mathrm{DNA}$ triplexes. 2-pyrimidinone as a nucleobase $\mathbf{2 5}$ was introduced to short PNA, which bound strongly to a homopurine tract of complementary RNA [84], while furan-modified uracil derivative $\mathbf{2 6}$ was designed as a mildly inducible, irreversible inter-strand crosslinking system targeting single and double-stranded DNA [85] 


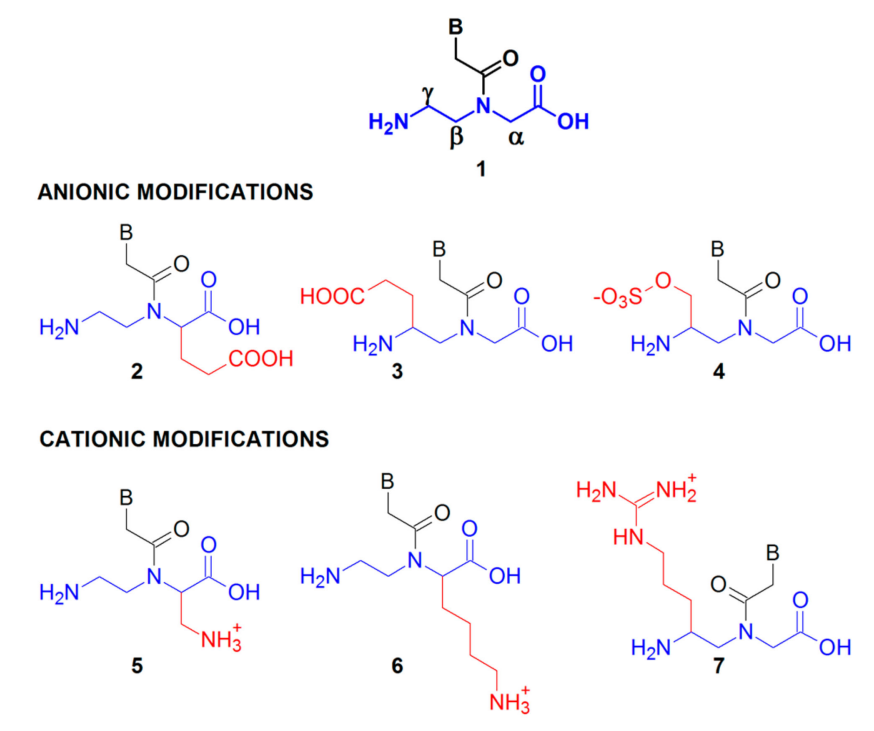

NEUTRAL MODIFICATIONS

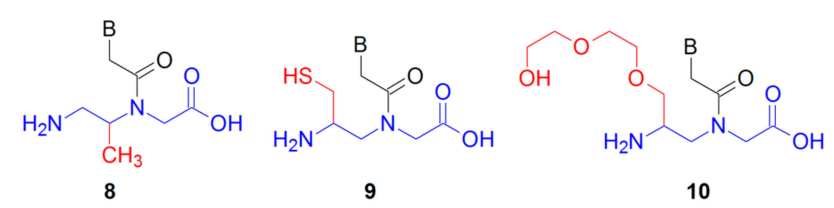

INTRODUCTION OF CARBOCYCLE/HETEROCYCLE

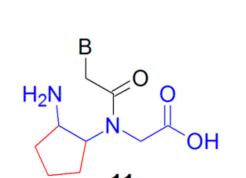

11<smiles>[B]C1CC(CN)N(CC(=O)O)C1</smiles><smiles>[B]C1CC(C(=O)O)N(CC[NH3+])C1</smiles>
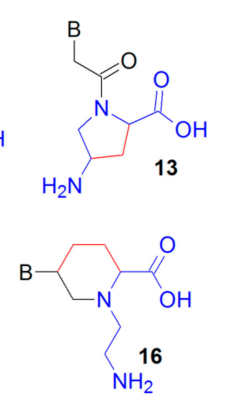

PHOSPHONO PNA

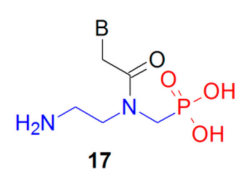

Figure 3. Selected modifications of the PNA backbone; the $N$-(2-aminoethyl)glycine backbone with the $\alpha-, \beta-$, or $\gamma$-position is shown in blue and the introduced modifications are shown in red. B stands for adenine, cytosine, guanine, or thymine.

Modifications of purine bases led to the development of 2,6-diaminopurine 27 applied to the design of pseudo-complementary PNA [86,87], 2-aminopurine $\mathbf{2 8}$ used as a fluorescent probe for examining PNA-DNA interaction dynamics [87,88], hypoxanthine 29, which could form Watson-Crick base pairs with adenine, cytosine, thymine, and uracil increasing the specificity of PNA [89,90], and 6-thioguanine 30, which caused helix distortion at the $6 \mathrm{sG}: \mathrm{C}$ base pair, but the base stacking throughout the duplex was still retained [91]. 
PYRIMIDINES<smiles>Nc1ncc([C+]=S)c(=O)[nH]c1=S</smiles><smiles>CCc1ccc(N)[nH+]c1</smiles><smiles>Cn1ccc(NC(=O)c2ccccc2)nc1=O</smiles><smiles>O=c1[nH]c(=O)n(C(F)(F)F)cc1Nc1c2ccccc2nc2ccccc12</smiles><smiles>Cn1cc(CNC(=O)Cc2ccc3ccc4cccc5ccc2c3c45)c(=O)[nH]c1=O</smiles><smiles>CC(C)(C)Cn1cccnc1=O</smiles><smiles>Cn1cc(Cn2cc(CNC(=O)CCc3ccco3)nn2)c(=O)[nH]c1=O</smiles>

PURINES<smiles>Cn1cnc2c(N)nc(N)nc21</smiles><smiles>CCn1cnc2cnc(N)nc21</smiles><smiles>CCn1cnc2c(=O)[nH]cnc21</smiles><smiles>Cn1cnc2c(=S)[nH]c(N)nc21</smiles>

VARIOUS MODIFICATIONS<smiles>Cn1cc2cc(-c3cccc(OCCNC(N)=[W])c3)[nH]c2nc1=O</smiles><smiles>NCCOc1cccc2c1Nc1nc(=O)n([Al])cc1O2</smiles><smiles>C[N+]1=CC=C(C=C2C=CN([13CH3])c3ccccc32)Sc2ccccc21</smiles><smiles>Fc1c(F)c(F)c2c(F)c([12F])c(F)c(F)c2c1F</smiles><smiles>[13CH3]n1c(=O)[nH]c(=O)[nH]c1=O</smiles>

Figure 4. Selected modifications of nucleobases in PNA monomers.

Finally, diverse heterocyclic bases were introduced in the place of either purine or pyrimidine bases. 2-Aminopyridine 31 was applied for the triplex-forming PNA [92], 3-oxo-2,3-dihydropyridazine monomer 32 was introduced to the PNA oligomer to increase affinity and selectivity of modified PNA to a microRNA [93]. Bicyclic 7-chloro-1,8-naphthyridin-2(1H)-one 33 turned out to be an effective thymine substitute in the PNA oligomers and increased PNA affinity in both duplex and triplex systems [94]. Introduction of tricyclic phenoxazine analog, 9-(2-aminoethoxy)phenoxazine (G-clamp) 34, enhanced the stability of PNA complexes with target nucleic acids [95,96]. Incorporation of the fluorescent dye, Thiazole Orange 35, enabled detection of homogeneous single nucleotide mutations [97]. One of the pyrrolocytosine bases 36 exhibited increased selectivity, binding affinity, and high fluorescence quantum yield in response to PNA hybridization [98]. Moreover, fluoroaromatic universal bases including 37 [99] and cyanuric acid derivatives as nucleobases 38 were applied to decrease base pairing discrimination by PNA probes, which could be desirable in some diagnostic applications [100].

Thanks to these advances in PNA chemistry, a number of modified PNA with properties better suited for biological applications have been presented. The aim of these changes was mainly to improve PNA affinity to natural nucleic acids, solubility, and membrane permeability. So far, no studies have been conducted with modified PNA oligomers as antibacterials. Although many new PNA analogs have been synthesized, still classical PNA monomers are most commonly used providing a reasonable balance between the requirement of high affinity for natural nucleic acids and specificity of the sequence recognition. Considering the problem of PNA delivery into bacteria, the most promising 
seem to be modifications that introduce positively charged groups into the PNA skeleton (compounds $5,6,7)$. Introduction of cationic groups into PNA should also improve its solubility and affinity to negatively charged nucleic acids.

Up to now, the $\gamma$-modified PNA was used as a diagnostic tool for identification of bacterial and fungal pathogens in blood [101]. This is one of the possible ways of using modified PNA in pathogen diagnostics. Furthermore, compared to conventional monomers, $\gamma$-PNA have several advantages: increased stability of duplexes with nucleic acids, better solubility, and less self-aggregation. Therefore, $\gamma$-modified PNA (e.g., compound number $3,4,7,9,10$ ) could be potentially useful also in antibacterial applications.

\section{Delivery of PNA to Bacteria}

In order to block the expression of a specific gene, PNA must first enter the bacterial cell. Unfortunately, PNA does not have the ability to spontaneously permeate bacterial membranes. Due to different transport mechanisms, effective delivery of PNA to bacteria is much more difficult than its delivery to mammalian cells. The main limitations hindering the development of antimicrobial PNA are poor PNA solubility in aqueous solutions, the lack of bacterial membrane permeability by PNA, and the associated difficulty of finding effective transporters of PNA to bacterial cells.

The cell wall of bacteria is an effective barrier for foreign particles, including PNA. Good et al. demonstrated that, in gram-negative bacteria, the main barrier for PNA is the lipopolysaccharide (LPS) - a component of the outer cell membrane [102]. They proved that Escherichia coli (E. coli) strains with defective LPS were more sensitive to PNA than strains without this modification. Overall, the antibacterial potential of PNA increased if $E$. coli was cultured in the presence of factors increasing cell wall permeability. However, PNA activity did not improve after introducing mutations in the genes encoding efflux pumps responsible for antibiotic resistance, suggesting that PNA is not a substrate for these pumps [102].

As mentioned above, poor water solubility and difficulty in delivering PNA to the cell interior are the major constraints in any PNA applications. Different strategies have been proposed to improve PNA bioavailability. One of them includes chemical modifications of the PNA backbone to increase PNA hydrophilicity (see the section on PNA modifications, e.g., the compound number 6 or 7, Figure 3). Another strategy is based on the conjugation of a PNA oligomer to positively charged amino acids at the PNA terminus $[103,104]$. An alternative is combining PNA with molecules capable of penetrating bacterial cells, which act as PNA transporters (Figure 5). In this section, we summarize available PNA delivery strategies used to achieve antimicrobial effects.

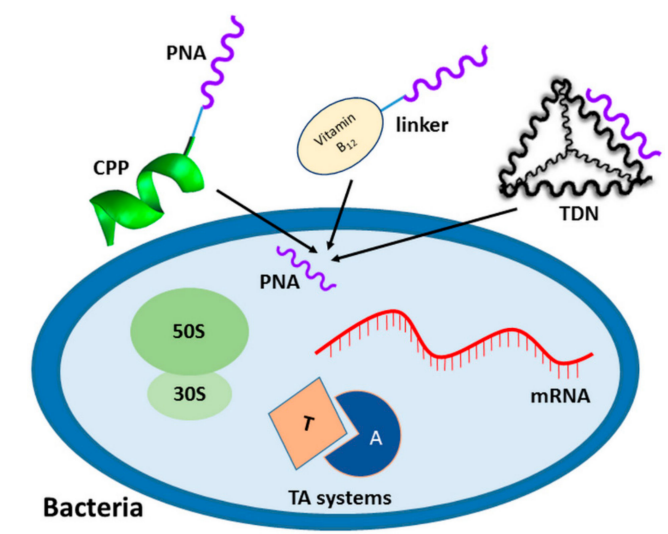

Figure 5. Schematic representation of PNA delivery strategies to bacterial cells: covalent conjugation of PNA with $\mathrm{CPP}$ or vitamin $\mathrm{B}_{12}$, and complementary base pairing between PNA and DNA in tetrahedral DNA nanostructure (TDN). PNA targets tested in bacteria: mRNA, ribosome, and toxin-antitoxin (TA) systems are also shown. 
Until now, the most effective way of transporting PNA to bacteria was by cell penetrating peptides (CPP), (Figure 5) [105]. CPP are short (usually consisting of less than $\mathbf{3 0}$ amino acids) cationic or amphipathic peptides that can transport molecules many times their weight. There are two ways to combine antisense oligonucleotides with CPP. One is the conjugation of a CPP with an oligonucleotide through a covalent bond, and the other one is the formation of a non-covalent complex [106]. Most CPP and PNA conjugates proposed so far are covalently linked.

The mechanism of cell penetration by CPP may be different for different bacteria. The most commonly used CPP that transports PNA into bacterial cells is the synthetic peptide $(\mathrm{KFF})_{3} \mathrm{~K}$, which was first synthesized by Vaara and Porro in 1996 [107] based on the skeleton of the antibiotic polymyxin B. $(\mathrm{KFF})_{3} \mathrm{~K}$ efficiently transports PNA in vitro, both to gram-negative and gram-positive cells [108]. Despite its efficiency in vitro, the activity of (KFF) ${ }_{3} \mathrm{~K}-\mathrm{PNA}$ conjugates drastically decreases in the presence of blood serum [109]. Moreover, this peptide causes hemolysis at concentrations above $32 \mu \mathrm{M}$ [107]; for comparison, polymyxin B is not hemolytic up to $1100 \mu \mathrm{M}$. Therefore, $(\mathrm{KFF})_{3} \mathrm{~K}$ is not an ideal candidate for a PNA transporter and its future medical use is doubtful.

Several other CPP have been tested as PNA carriers in vitro, including $(\mathrm{RXR})_{4} \mathrm{XB}$ (X-6-aminohexanoic; B- $\beta$-alanine) [110], the TAT peptide produced by human immunodeficiency virus [111], and many others [112,113]. Abushahba et al. [112] tested the antibacterial effect of PNA attached to five different CPP. In this work, PNA inhibited the $r p o A$ gene, which is the key gene for the survival of Listeria monocytogenes. The authors confirmed that (RXR $)_{4} \mathrm{XB}, \mathrm{TAT}$ and $(\mathrm{RFR})_{4} \mathrm{XB}$, are the most effective in introducing PNA into L. monocytogenes. The same peptides were tested by the Patenge group [105] and conjugated to PNA complementary to the fragment of the gyrA gene in order to inhibit the growth of Streptococus pyogenes. Out of 18 different peptides, TAT, oligolysine (K8), and (RXR) 4 XB, effectively inhibited the growth of the tested strains.

The first protein identified as involved in the transport of peptide-PNA conjugates is an inner membrane protein SbmA [114]. Ghosal et al. have shown that first, the peptide-PNA conjugate passes through the outer membrane, then the peptide carrier is degraded by proteases, and next, SbmA is involved in the transport of the free PNA through the inner membrane. However, in another work, it was shown that the SbmA protein is not always required for antibacterial activity of the peptide-PNA conjugate [115]. Hansen et al. tested 16 conjugates of PNA with antimicrobial peptides. They identified three SbmA-independent, antimicrobially active PNA conjugates with peptides: Pep-1-K, KLW-9,13- $\alpha$ and drosocin-RXR. In addition, in [116] it was shown that the involvement of SbmA in the peptide-PNA transport also depends on the length of the PNA oligomer.

The effectiveness of PNA delivery into bacteria using CPP can be modulated by the linker between the PNA and peptide (using either a degradable or non-degradable one) $[117,118]$. The most commonly used linker in the CPP-PNA conjugates is a flexible ethylene glycol linker [105,116]. Good et al. [11] compared two antibacterial CPP-PNA conjugates with the same sequence but different linkers (degradable, maleimide; and non-degradable, ethylene glycol). They showed that the conjugate with the degradable linker is 10 times less active against $E$. coli than the conjugate with the ethylene glycol linker. Many other linkers were tested, e.g., a stable triazole ring [119] or degradable disulfide bond $[117,120]$. We found that the conjugates with the ethylene glycol linker showed improved antimicrobial activity as compared to the same conjugates but connected through the triazole ring (unpublished observation). A comprehensive comparison of different linkers in peptide conjugates with different oligonucleotides can be found in the review [121].

Note, that CPP as PNA carriers are not universal because the transport of CPP may be strain dependent. Additional obstacle in the use of CPP is that they may be cytotoxic to eukaryotic cells and cause hemolysis of erythrocytes [107,122]. Therefore, there is still a need to develop effective and noninvasive methods of introducing short, modified oligonucleotides (such as PNA oligomers) into bacterial cells.

Beyond CPP, few non-peptidic molecules have been investigated to actively transport PNA to bacteria. One such carrier of PNA is vitamin $B_{12}$ (Figure 5). All aerobic bacteria require vitamin $B_{12}$ for 
growth, but only a few produce it de novo [123] therefore, most microorganisms are forced to take up vitamin $B_{12}$ from the environment. In recent years, PNA was combined with vitamin $B_{12}$ using different linkers. Vitamin $B_{12}$ was also found to improve PNA solubility and make the PNA in the conjugate adopt a more extended conformation in comparison with free single-stranded PNA [124]. Furthermore, we have shown that vitamin $B_{12}$ acts as a carrier of PNA to E. coli and Salmonella enterica subsp. enterica serovar Typhimurium $[119,125]$. These studies indicate that vitamin $B_{12}$ could be a good candidate for a PNA transporter into bacteria. However, the concentrations of vitamin $B_{12}$ required for bacterial growth are smaller than the concentrations of PNA that are necessary to exert an antibacterial effect.

An interesting and innovative approach was proposed in the work Readman et al. [126]. The self-assembling three-dimensional structure of a DNA tetrahedron was used as a carrier for PNA oligomers into E. coli (Figure 5). The authors developed a DNA tetrahedron vector based on a single-stranded DNA incorporating a PNA into its structural design. The PNA-tetrahedral DNA nanostructure (TDN) inhibited bacterial growth at lower concentrations than the previously reported $(\mathrm{KFF})_{3} \mathrm{~K}-\mathrm{PNA}$ conjugate [126]. The transport mechanism of such complexes is not clear and further studies of this vector are needed. Nevertheless, TDNs are promising candidates for PNA vectors because they are non-toxic to cells as compared to CPP. In another work [127], TDNs efficiently transported antisense PNA (targeting the ftsZ gene) into methicillin-resistant Staphylococcus aureus.

Despite these few other strategies to deliver PNA to bacteria, the covalent conjugation of PNA and CPP is still the most popular one, mainly due to well-developed and relatively easy synthesis protocols. These protocols allow quick changes of the peptide sequence, PNA attachment site, and the linker type. However, this way of delivering PNA to bacteria is not ideal. Peptide uptake depends on bacterial strain and, at high concentrations, CPP exhibit toxicity to both bacterial and eukaryotic cells. Importantly, the new carriers such as vitamin $\mathrm{B}_{12}$ and TDN have proven that we do not have to limit ourselves to cationic peptides and completely different (non-peptidic) types of transporters could be considered and tested.

\section{Applications of PNA as an Antibacterial Agent}

In this section, we summarize the PNA sequences used as antibacterials. Since it is impossible to list all the PNA-targeted genes and strains, we overview the most promising reports presenting the lowest minimal inhibitory concentrations (MIC) necessary to inhibit bacterial growth. Table 2 summarizes the MIC values for different $(\mathrm{KFF})_{3} \mathrm{~K}-\mathrm{PNA}$ conjugates aimed at various targets and bacterial strains. Note, that the summary in Table 2 is only indicative of PNA antibacterial activity because it is impossible to compare the effectiveness of different PNA sequences that target different stages of bacterial metabolism. Also, the $(\mathrm{KFF})_{3} \mathrm{~K}$ carrier may work differently in different strains. Similarly, it is impossible to compare the activity of PNA with classical antibiotics. Nevertheless, the MIC values in Table 2 are promising and motivate further research on antibacterial PNA.

\subsection{Targeting the mRNA of Essential Genes with Antisense PNA}

In the last two decades, many mRNA encoding essential genes in clinically pathogenic bacteria have been validated as possible targets for antisense PNA (Table 2). The most effective were PNA designed as complementary to mRNA around the start codon and its neighboring region. By binding to mRNA, PNA acts as a steric hindrance, contrary to some other oligonucleotides that induce the activity of RNase $\mathrm{H}$.

The first reported antibacterial PNA targeted the mRNA transcript of E. coli acpP gene that encodes the acyl carrier protein, a protein crucial in fatty acid biosynthesis [11]. The acpP gene is conserved among gram-negative bacteria and has become a frequent PNA target in various human pathogens such as: Brucella suis [128], Haemophilus influenza [129], Pseudomonas aeruginosa [130]. In addition, a fabI gene, also involved in fatty acid biosynthesis, was targeted in E. coli and S. aureus [131]. The E. coli growth was also inhibited by PNA directed at mRNA involved in the folate biosynthesis ( $f \circ l A$ and folP) [131]. 
To improve the antimicrobial activity, PNA have also been used in combination with antibiotics. Dryselius et al. and Castillo et al. analysed synergistic interactions between PNA targeting fatty acid and folate synthesis pathways and a series of conventional antibiotics used against E. coli [131,132]. Antibiotics were selected based on their clinical relevance and targeted various biosynthetic pathways. These included aminoglycosides, penicillins, polymyxins, rifamycins, sulfonamides, and trimethoprim. The authors found several new synergistic combinations. Surprisingly, in both studies, higher synergy of action was reported for inhibitor combinations with functionally unrelated targets than for combinations with related targets.

Dryselius et al. examined the effects of the combinations of PNA and drugs against folate biosynthesis: sulfonamides that target dihydropteroate synthase (of the folP gene) in an early step of folate biosynthesis, and trimethoprim that inhibits dihydrofolate reductase (of the fol $A$ gene) in the later step of this pathway. They synergy was observed if the anti-folA PNA was combined with sulfamethoxazole, but no synergy was detected if anti-folP PNA was combined with trimethoprim [131]. Similarly, Castillo et al. demonstrated that PNA targeted at the essential acpP gene (involved in biosynthesis of fatty acids) exhibited synergistic interaction with trimethoprim, whose target is unrelated [132]. The molecular mechanisms of synergistic actions of these combinations are yet undiscovered and require further investigations. By contrast, Patenge et al. found antimicrobial synergy against $S$. pyogenes for the combination of anty-gyrA PNA with levofloxacin and novobiocin, agents that share the same target, namely the gyrase enzyme [111]. These synergy observations suggest that antisense PNA are promising candidates for a combination therapy and could be applied to improve the effectiveness of already used drugs. This could help delay or prevent the development of resistance to respective drugs.

Other essential biological processes that have been disrupted by antisense PNA, in both gram-negative and gram-positive bacteria, are DNA transcription and replication. Respectively, the rpoD gene encoding RNA polymerase and gyrA encoding DNA gyrase were targeted by PNA in several pathogens including S. pyogenes [111], S. aureus, S. Typhimurium and Shigella flexneri [110] (Table 2). Besides, PNA have also been used to inhibit the growth of Mycobacterium smegmatis [133] and the intracellular pathogen L. monocytogenes [112].

Interestingly, PNA targeted to specific sites of selected genes in Bacillus subtilis (ftsZ gene), E. coli (murA), Klebsiella pneumoniae (murA), and S. Typhimurium (murA, ftsZ) in a mixed culture, selectively killed bacteria [134]. These findings open a novel opportunity for designing selective therapeutic interventions for eradication of pathogenic bacteria.

Importantly, the efficacy of the antimicrobial peptide-PNA targeting mRNA was also demonstrated in a mouse model of infection. Tan et al. showed that injection of the antisense peptide-PNA targeting the acpP gene significantly inhibited the growth of E. coli strains in mice [135]. Moreover, Abushahba et al. reported selective inhibition of L. monocytogenes growth in vitro, in cell culture, and in the Caenorhabditis elegans infection model. They also demonstrated that the PNA sequence did not adversely affect mitochondrial protein synthesis [112].

\subsection{Ribosome as a Target for Antibacterial PNA}

Many antibiotics exert their antimicrobial effects by binding to bacterial ribosome and interfering with protein synthesis (Figure 5) [136]. Three-dimensional structures of bacterial ribosomes were determined by X-ray crystallography showing that rRNA could be a promising target for the PNA oligomers. In fact, several studies demonstrated that PNA oligomers binding to the functional domains of both 23S and 16S rRNA effectively inhibited E. coli cell growth. For example, Good et al., used PNA oligomers to strand-invade and disrupt peptidyl transferase center (PTC) and $\alpha$-sarcin loop of the 23S rRNA in the 50S ribosome subunit [137]. These PNA effectively inhibited translation in a cell-free system, as well as the growth of E. coli AS19 cells (Table 2). The PTC is the catalytic center of the ribosome, in which peptide bonds are formed between adjacent amino acids, so it is an essential ribosome part providing its enzymatic function. The $\alpha$-sarcin loop interacts with ribosome 
elongation factors and is a target for cytotoxins, such as $\alpha$-sarcin and ricin, which completely abolishes translation [138]. In another study, Kulik et al. inhibited E. coli growth with a PNA oligomer targeting a fragment of the 23S rRNA, called Helix 69 [139] (Table 2). Helix 69 forms an inter-subunit connection between the $50 \mathrm{~S}$ and $30 \mathrm{~S}$ ribosomal subunits and also binds some aminoglycoside antibiotics.

PNA have been also designed to bind $16 \mathrm{~S}$ rRNA [137,140,141]. Hatamoto et al. tested PNA oligomers targeting several conserved regions of 16S rRNA using an in vitro translation assay. They found that only PNA directed against the mRNA binding site of 16S rRNA inhibited translation in a cell-free system. Furthermore, they investigated the inhibitory effect of PNA on the growth of E. coli K-12, Bacillus subtilis 168 and Corynebacterium efficiens YS-314 (Table 2) [140]. Importantly, besides the mRNA binding site, many other 16S rRNA regions of importance for ribosome function have been found. Górska et al., formulated the protocol that identifies regions in 16S rRNA as potential targets for sequence-specific binding and inhibition of the ribosome function [142]. The authors assessed 16S rRNA target accessibility, flexibility, and energy of strand invasion by a PNA oligomer, as well as similarity to human rRNA. They also designed and tested a PNA oligomer complementary to the 830-839 fragment of 16S rRNA of E. coli, which, in this particular site, is also identical in $S$. Typhimurium, and confirmed that this PNA sequence inhibited bacterial growth (Table 2) [142].

\subsection{Other mRNA Targets}

Apart from targeting the essential mRNA and rRNA, PNA oligomers were also tested against other bacterial targets, including non-essential genes. Many bacterial species form extracellular biofilms making infections extremely challenging to eradicate. Hu et al. found a PNA oligomer that effectively inhibited biofilm formation [143]. This PNA targeted the mRNA of the motA gene, encoding the element of the flagellar motor complex, in Pseudomonas aeruginosa. The biofilm formation was also hindered in Enterococcus faecalis by a PNA directed at the efa $A$ gene, which plays an important role in the adhesion of bacteria to surfaces [144]. Besides biofilm-related genes, antibiotic resistance genes can be targeted to increase the susceptibility of resistant bacteria to antibiotics. For example, PNA aimed at a multi-drug efflux pump cmeABC of Campylobacter jejuni increased the susceptibility of this strain to ciprofloxacin and erythromycin [145].

A separate approach describes the design of a PNA-based treatment that exploits the mazEF and hipBA toxin-antitoxin systems (Figure 5) as novel targets for antisense antibacterials in a multi-drug resistant E. coli [146]. Many bacteria have toxin-antitoxin systems, typically composed of two genes, one encoding a toxin that targets an essential cellular process, and the other an antitoxin that counteracts the toxin activity. Równicki et al. showed that PNA can be used to modulate the expression of the toxin-antitoxin system. They found that antisense PNA effectively terminate translation of the antitoxin, causing bacterial cell death. Promisingly, the PNA oligomers did not activate cytotoxicity in mammalian cells [146].

Table 2. Minimal inhibitory concentrations (MICs) determined for (KFF) ${ }_{3} \mathrm{~K}-\mathrm{PNA}$ conjugates targeted at various genes. The MIC values provided in the table are the lowest determined MICs in each case.

\begin{tabular}{|c|c|c|c|c|}
\hline Target & Function & Bacteria & $\mathrm{MIC}^{*}(\mu \mathrm{M})$ & Reference \\
\hline \multicolumn{5}{|c|}{ mRNA of essential genes } \\
\hline \multirow{4}{*}{$a c p P$} & \multirow{5}{*}{ fatty acid biosynthesis } & Brucella suis 1330 & $30 * *$ & {$[128]$} \\
\hline & & Escherichia coli $\mathrm{K}-12$ & 0.6 & {$[11]$} \\
\hline & & Haemophilus influenza & 0.6 & {$[129]$} \\
\hline & & Pseudomonas aeruginosa PAO1 & 2 & {$[130]$} \\
\hline$h m r B$ & & Staphylococcus aureus RN4220 & 10 & {$[122]$} \\
\hline \multirow[b]{2}{*}{$f a b I$} & & Escherichia coli $\mathrm{K}-12$ & 3 & \multirow{4}{*}[131]{} \\
\hline & & Staphylococcus aureus RN4220 & 15 & \\
\hline folA & \multirow{2}{*}{ folate biosynthesis } & Escherichia coli AS19 & 2.5 & \\
\hline folP & & Escherichia coli AS19 & 2.5 & \\
\hline
\end{tabular}


Table 2. Cont.

\begin{tabular}{|c|c|c|c|c|}
\hline Target & Function & Bacteria & $\mathrm{MIC}^{*}(\mu \mathrm{M})$ & Reference \\
\hline \multicolumn{5}{|c|}{ mRNA of essential genes } \\
\hline \multirow{5}{*}{ gyrA } & \multirow{5}{*}{ DNA replication } & Acinetobacter baumanii CY-623 & 5 & [147] \\
\hline & & Brucella suis 1330 & 30 & [128] \\
\hline & & Klebsiella pneumoniae & 20 & [148] \\
\hline & & Staphylococcus aureus RN4220 & 10 & [131] \\
\hline & & Streptococcus pyogenes & & [111] \\
\hline \multirow{6}{*}{$r p o D$} & \multirow{6}{*}{ DNA transcription } & Escherichia coli (ESBL+) & 6.2 & [110] \\
\hline & & Klebsiella pneumoniae (ESBL+) & 30 & [110] \\
\hline & & Listeria monocytogenes ATCC 19114 & $2 * * *$ & [112] \\
\hline & & $\begin{array}{l}\text { Salmonella enterica serovar } \\
\text { Typhimurium LT2 }\end{array}$ & $15^{* * *}$ & [149] \\
\hline & & Shigella flexneri (MDR) & 5 & [110] \\
\hline & & Staphylococcus aureus ATCC29213 & 6.2 & [108] \\
\hline \multirow{3}{*}{ murA } & \multirow{3}{*}{ cell-wall biogenesis } & Escherichia coli DH10B & 2.4 & \multirow{3}{*}{ [134] } \\
\hline & & Klebsiella pneumoniae ATCC 700721 & 2.5 & \\
\hline & & $\begin{array}{l}\text { Salmonella enterica serovar } \\
\text { Typhimurium LT2 }\end{array}$ & 1.2 & \\
\hline \multirow[b]{2}{*}{ ftsZ } & \multirow[b]{2}{*}{ cell division } & Bacillus subtilis 168 & 4 & \multirow[b]{2}{*}{ [134] } \\
\hline & & $\begin{array}{l}\text { Salmonella enterica serovar } \\
\text { Typhimurium LT2 }\end{array}$ & 2.5 & \\
\hline $\operatorname{inh} A$ & mycolic acid biosynthesis & Mycobacterium smegmatis 155 & $<5$ & [133] \\
\hline \multicolumn{5}{|c|}{ rRNA } \\
\hline PTC & $\begin{array}{l}\text { peptidyl transferase center } \\
\text { 23S rRNA }\end{array}$ & Escherichia coli K-12 & $50 * * *$ & \multirow{2}{*}{ [137] } \\
\hline a-sarcin loop & $\begin{array}{l}\text { binds elongation factor } \mathrm{G} \\
(\mathrm{EF}-\mathrm{G}) 23 \mathrm{~S} \text { rRNA }\end{array}$ & Escherichia coli K-12 & $50^{* * *}$ & \\
\hline Helix 69 & $\begin{array}{l}\text { forms connection between } \\
\text { ribosomal subunits }\end{array}$ & Escherichia coli K-12 & 15 & [139] \\
\hline \multirow{3}{*}{ mRBS } & \multirow{3}{*}{$\begin{array}{l}\text { mRNA binding site } 16 S \\
\text { rRNA }\end{array}$} & Corynebacterium efficiens & 2 & \multirow{3}{*}{ [140] } \\
\hline & & Bacillus subtilis & 5 & \\
\hline & & Escherichia coli $\mathrm{K}-12$ & 10 & \\
\hline $\begin{array}{l}\text { 830-839 16S } \\
\text { RNA }\end{array}$ & $\begin{array}{c}\text { part of IF3 binding site 16S } \\
\text { rRNA }\end{array}$ & Escherichia coli K-12 & 15 & \multirow{2}{*}{ [142] } \\
\hline $\begin{array}{l}\text { 830-839 16S } \\
\text { RNA }\end{array}$ & $\begin{array}{l}\text { part of IF3 binding site 16S } \\
\text { rRNA }\end{array}$ & $\begin{array}{l}\text { Salmonella enterica serovar } \\
\text { Typhimurium LT2 }\end{array}$ & 5 & \\
\hline \multicolumn{5}{|c|}{ Other mRNA targets } \\
\hline mot $A$ & biofilm formation & Pseudomonas aeruginosa $\mathrm{PAO} 1$ & 1 & [143] \\
\hline cmeABC & $\begin{array}{l}\text { multidrug efflux } \\
\text { transporter }\end{array}$ & Campylobacter jejuni & - & [145] \\
\hline mazE & antitoxin MazE & Escherichia coli WR3551/98 & 16 & \multirow{4}{*}{ [146] } \\
\hline hipB & antitoxin HipB & Escherichia coli WR3551/98 & 16 & \\
\hline thyA & thymidylate synthase & Escherichia coli WR3551/98 & 16 & \\
\hline gltX & glutamyl-tRNA synthetase & Escherichia coli WR3551/98 & 2 & \\
\hline
\end{tabular}

* MICs were tested in Mueller-Hinton broth, unless otherwise stated ${ }^{* *}$ MICs were tested in Tryptic Soy broth

*** Inhibition assays performed using solid LB/agar plates.

As shown in Table 2, in the last two decades, many PNA targets in bacteria have been found and successfully verified. Still, the main PNA target in antibacterial applications of PNA is mRNA of 
essential genes. However, because of the complicated RNA architecture, and thus unknown mRNA fold, it is not easy to predict if the PNA-mRNA complex is formed. In addition, finding a PNA susceptible target that is present in bacteria and not present in mammalian cells is as fundamental as finding an efficient PNA carrier to bacterial cells. Contrary to other small molecule compounds, virtually any bacterial RNA can be targeted by antisense PNA, offering a limitless set to choose from. Since novel antibiotic targets are constantly searched for, they could be tested by using PNA and vice versa, PNA could also help identify them $[150,151]$.

\section{Conclusions}

The use of sequence-specific oligonucleotides binding to natural nucleic acid targets has been a matter of extensive research, finally leading to a few FDA-approved oligonucleotide-based therapies in humans [152]. PNA as a nucleic acid mimic has been investigated for nearly 30 years. Since its first synthesis, the physicochemical properties of PNA and its interactions-especially with DNA-have been well determined. PNA oligomers have been tested in various applications, not only as antimicrobials but also as antiviral or anticancer molecules [12,153,154].

Nevertheless, the use of PNA as an antibiotic is not foreseen in the near future due to crucial limitations. The main drawback precluding the use of PNA as an antimicrobial is its lack of uptake by bacterial cells. Even though some positive examples of PNA carriers have been shown, mainly cell-penetrating peptides, we have not yet found effective PNA transporters to bacterial cells. Using modified PNA monomers could help achieve better PNA solubility and membrane permeability. Also, not only covalently bound peptides should be considered as PNA carriers, but also non-peptidic transporters. In addition, to lower the concentrations of PNA required to inhibit bacterial growth (thus PNA doses), not only an effective PNA carrier is needed but also a more PNA-susceptible target. Thus, future efforts should also focus on the search for novel PNA targets that go beyond mRNA encoding essential proteins. Despite these limitations, PNA shows promise in antibacterial studies because of its high binding affinity to RNA and strand-invasion capability. Studies highlighted in this review point to effective antibacterial PNA sequences. However, the majority of PNA sequences were tested in vitro and many questions on the PNA use in vivo still remain to be answered. Few reports have shown PNA efficacy in animal models of infection using clinically relevant doses, but most studies were performed in non-human models. Therefore, how PNA affects the interferon response and emergence of bacterial resistance remains to be seen.

It is worth noting that PNA use has already been successful in detection of bacterial pathogens. The use of PNA in diagnosis of bacterial infections has gained a lot of attention because it is critical to quickly recognize a particular pathogen to administer proper medication. The new pathogen identification platform based on the interaction of $\gamma$-PNA with double-stranded DNA shows promise in diagnostics [101]. Thus, PNA research related to bacterial applications has also focused on the diagnostic applications [155-157].

The number of studies related to the use of PNA in antibacterial applications is constantly growing, with PNA as a diagnostic tool for detecting pathogens paving the way. Thus, in the future the development of PNA-based antibiotics could become an alternative approach in the fight against multi-drug bacterial resistance. Other possibilities of PNA are yet to be discovered.

Author Contributions: All authors wrote and edited this review. All authors have read and agreed to the published version of the manuscript.

Funding: This research was funded by the National Science Centre, Poland UMO-2016/23/B/NZ1/03198 to MW and JT, 2019/03/X/NZ1/00077 to MW, and 2017/25/N/NZ1/01578 to MR.

Conflicts of Interest: The authors declare no conflict of interest. 


\section{References}

1. Antimicrobial Resistance. Available online: http://www.who.int/news-room/fact-sheets/detail/antimicrobialresistance (accessed on 19 November 2019).

2. Walsh, F. Superbugs to Kill “More than Cancer” by 2050. Available online: http://www.bbc.com/news/health30416844 (accessed on 19 November 2019).

3. Ventola, C.L. The antibiotic resistance crisis: Causes and threats. Pharm. Ther. 2015, 40, 277-283.

4. Ventola, C.L. The antibiotic resistance crisis: Part 2: Management strategies and new agents. Pharm. Ther. 2015, 40, 344-352.

5. Chandrika, N.T.; Garneau Tsodikova, S. A review of patents (2011-2015) towards combating resistance to and toxicity of aminoglycosides. Med. Chem. Commun. 2016, 7, 50-68. [CrossRef] [PubMed]

6. Nielsen, P.E.; Egholm, M.; Berg, R.H.; Buchardt, O. Sequence-selective recognition of DNA by strand displacement with a thymine-substituted polyamide. Science 1991, 254, 1497-1500. [CrossRef]

7. Demidov, V.V.; Potaman, V.N.; Frank-Kamenetskil, M.D.; Egholm, M.; Buchard, O.; Sönnichsen, S.H.; Nlelsen, P.E. Stability of peptide nucleic acids in human serum and cellular extracts. Biochem. Pharmacol. 1994, 48, 1310-1313. [CrossRef]

8. Demidov, V.; Frank-kamenetskii, M.D.; Egholm, M.; Buchardt, O.; Nielsen, P.E. Sequence selective double strand DNA cleavage by peptide nucleic acid (PNA) targeting using nuclease S1. Nucleic Acids Res. 1993, 21, 2103-2107. [CrossRef]

9. Casale, R.; Jensen, I.S.; Egholm, M. Synthesis of PNA oligomers by Fmoc chemistry. In ChemInform; Nielsen, P.E., Ed.; Horizon Bioscience: Norfolk, UK, 2005; pp. 61-76. ISBN 978-0-9545232-4-4.

10. Lundin, K.E.; Good, L.; Strömberg, R.; Gräslund, A.; Smith, C.I.E. Biological activity and biotechnological aspects of peptide nucleic acid. Adv. Genet. 2006, 56, 1-51. [CrossRef]

11. Good, L.; Awasthi, S.K.; Dryselius, R.; Larsson, O.; Nielsen, P.E. Bactericidal antisense effects of peptide PNA conjugates. Nat. Biotechnol. 2001, 19, 360-364. [CrossRef]

12. Gupta, A.; Mishra, A.; Puri, N. Peptide nucleic acids: Advanced tools for biomedical applications. J. Biotechnol. 2017, 259, 148-159. [CrossRef]

13. Saarbach, J.; Sabale, P.M.; Winssinger, N. Peptide nucleic acid (PNA) and its applications in chemical biology, diagnostics, and therapeutics. Curr. Opin. Chem. Biol. 2019, 52, 112-124. [CrossRef]

14. Hatamoto, M.; Ohashi, A.; Imachi, H. Peptide nucleic acids (PNAs) antisense effect to bacterial growth and their application potentiality in biotechnology. Appl. Microbiol. Biotechnol. 2010, 86, 397-402. [CrossRef] [PubMed]

15. Ghosal, A. Peptide nucleic acid antisense oligomers open an avenue for developing novel antibacterial molecules. J. Infect. Dev. Ctries. 2017, 11, 212-214. [CrossRef] [PubMed]

16. Xue, X.Y.; Mao, X.G.; Zhou, Y.; Chen, Z.; Hu, Y.; Hou, Z.; Li, M.K.; Meng, J.R.; Luo, X.X. Advances in the delivery of antisense oligonucleotides for combating bacterial infectious diseases. Nanomed. Nanotechnol. Biol. Med. 2018, 14, 745-758. [CrossRef] [PubMed]

17. Sully, E.K.; Geller, B.L. Antisense antimicrobial therapeutics. Curr. Opin. Microbiol. 2016, 33, 47-55. [CrossRef] [PubMed]

18. Lee, H.T.; Kim, S.K.; Yoon, J.W. Antisense peptide nucleic acids as a potential anti-infective agent. J. Microbiol. 2019, 57, 423-430. [CrossRef] [PubMed]

19. Berman, H.M. The protein data bank http://www.rcsb.org/pdb/. Nucleic Acids Res. 2000, 28, $235-242$. [CrossRef]

20. Eldrup, A.B.; Nielsen, B.B.; Haaima, G.; Rasmussen, H.; Kastrup, J.S.; Christensen, C.; Nielsen, P.E. 1,8-Naphthyridin-2(1H)-ones - Novel Bicyclic and Tricyclic Analogues of Thymine in Peptide Nucleic Acids (PNAs). European J. Org. Chem. 2001, 2001, 1781-1790. [CrossRef]

21. He, W.; Hatcher, E.; Balaeff, A.; Beratan, D.N.; Gil, R.R.; Madrid, M.; Achim, C. Solution structure of a peptide nucleic acid duplex from NMR data: Features and limitations. J. Am. Chem. Soc. 2008, 130, 13264-13273. [CrossRef]

22. Rasmussen, H.; Kastrup, S.J.; Nielsen, J.N.; Nielsen, J.M.; Nielsen, P.E. Crystal structure of a peptide nucleic acid (PNA) duplex at $1.7 \AA ̊$ resolution. Nat. Struct. Biol. 1997, 4, 98-101. [CrossRef] 
23. Rasmussen, H.; Liljefors, T.; Petersson, B.; Nielsen, P.E.; Kastrup, J.S. The influence of a chiral amino acid on the helical handedness of PNA in solution and in crystals. J. Biomol. Struct. Dyn. 2004, 21, 495-502. [CrossRef]

24. Petersson, B.; Nielsen, B.B.; Rasmussen, H.; Larsen, I.K.; Gajhede, M.; Nielsen, P.E.; Kastrup, J.S. Crystal structure of a partly self-complementary peptide nucleic acid (PNA) oligomer showing a duplex-triplex network. J. Am. Chem. Soc. 2005, 127, 1424-1430. [CrossRef] [PubMed]

25. He, W.; Crawford, M.J.; Rapireddy, S.; Madrid, M.; Gil, R.R.; Ly, D.H.; Achim, C. The structure of a $\gamma$-modified peptide nucleic acid duplex. Mol. Biosyst. 2010, 6, 1619-1629. [CrossRef] [PubMed]

26. Yeh, J.I.; Pohl, E.; Truan, D.; He, W.; Sheldrick, G.M.; Du, S.; Achim, C. The crystal structure of non-modified and bipyridine-modified PNA duplexes. Chem. A Eur. J. 2010, 16, 11867-11875. [CrossRef] [PubMed]

27. Haaima, G.; Rasmussen, H.; Schmidt, G.; Jensen, D.K.; Kastrup, J.S.; Stafshede, P.W.; Nordén, B.; Buchardt, O.; Nielsen, P.E. Peptide nucleic acids (PNA) derived from $N$-( $N$-methylaminoethyl)glycine. Synthesis, hybridization and structural properties. New J. Chem. 1999, 23, 833-840. [CrossRef]

28. Kiliszek, A.; Banaszak, K.; Dauter, Z.; Rypniewski, W. The first crystal structures of RNA-PNA duplexes and a PNA-PNA duplex containing mismatches - Toward anti-sense therapy against TREDs. Nucleic Acids Res. 2015, 44, 1937-1943. [CrossRef] [PubMed]

29. Cuesta-Seijo, J.A.; Zhang, J.; Diederichsen, U.; Sheldrick, G.M. Continuous $\beta$-turn fold of an alternating alanyl/homoalanyl peptide nucleic acid. Acta Crystallogr. Sect. D Biol. Crystallogr. 2012, 68, 1067-1070. [CrossRef] [PubMed]

30. Brown, S.; Thomson, S.; Veal, J.; Davis, D. NMR solution structure of a peptide nucleic acid complexed with RNA. Science 1994, 265, 777-780. [CrossRef]

31. Eriksson, M.; Nielsen, P.E. Solution structure of a peptide nucleic acid-DNA duplex. Nat. Struct. Biol. 1996, 3, 410-413. [CrossRef]

32. Menchise, V.; De Simone, G.; Tedeschi, T.; Corradini, R.; Sforza, S.; Marchelli, R.; Capasso, D.; Saviano, M.; Pedone, C. Insights into peptide nucleic acid (PNA) structural features: The crystal structure of a D-lysine-based chiral PNA-DNA duplex. Proc. Natl. Acad. Sci. USA 2003, 100, 12021-12026. [CrossRef]

33. Yeh, J.I.; Shivachev, B.; Rapireddy, S.; Crawford, M.J.; Gil, R.R.; Du, S.; Madrid, M.; Ly, D.H. Crystal structure of chiral $\gamma$ pNA with complementary DNA strand: Insights into the stability and specificity of recognition and conformational preorganization. J. Am. Chem. Soc. 2010, 132, 10717-10727. [CrossRef]

34. Betts, L.; Josey, J.A.; Veal, J.M.; Jordan, S.R. A nucleic acid triple helix formed by a peptide nucleic acid-DNA complex. Science 1995, 270, 1838. [CrossRef] [PubMed]

35. Bentin, T.; Larsen, H.J.; Nielsen, P.E. Poptide nucleic acid targeting of double-stranded DNA. In PEPTIDE NUCLEIC ACIDS Protocols and Applications; Nielsen, P.E., Ed.; Horizon Bioscience: Norfolk, UK, 2005; pp. 107-140. ISBN 978-0-9545232-4-4.

36. Nielsen, P.E. Peptide nucleic acid. A molecule with two identities. Acc. Chem. Res. 1999. [CrossRef]

37. Egholm, M.; Christensen, L.; Deuholm, K.L.; Buchardt, O.; Coull, J.; Nielsen, P.E. Efficient pH-independent sequence-specific DNA binding by pseudoisocytosine-containing bis-PNA. Nucleic Acids Res. 1995, 23, 217-222. [CrossRef] [PubMed]

38. Griffith, M.C.; Risen, L.M.; Greig, M.J.; Lesnik, E.A.; Sprankle, K.G.; Griffey, R.H.; Kiely, J.S.; Freier, S.M. Single and bis peptide nucleic acids as triplexing agents: Binding and stoichiometry. J. Am. Chem. Soc. 1995, 117, 831-832. [CrossRef]

39. Nielsen, P.E.; Christensen, L. Strand displacement binding of a duplex-forming homopurine PNA to a homopyrimidine duplex DNA target. J. Am. Chem. Soc. 1996, 118, 2287-2288. [CrossRef]

40. Lohse, J.; Dahl, O.; Nielsen, P.E. Double duplex invasion by peptide nucleic acid: A general principle for sequence-specific targeting of double-stranded DNA. Proc. Natl. Acad. Sci. USA 1999, 96, 11804-11808. [CrossRef]

41. Demidov, V.V.; Protozanova, E.; Izvolsky, K.I.; Price, C.; Nielsen, P.E.; Frank-Kamenetskii, M.D. Kinetics and mechanism of the DNA double helix invasion by pseudocomplementary peptide nucleic acids. Proc. Natl. Acad. Sci. USA 2002, 99, 5953-5958. [CrossRef]

42. Ratilainen, T.; Nordén, B. Thermodynamics of PNA interactions with DNA and RNA. Methods Mol. Biol. 2002, 208, 59-88. [CrossRef] 
43. Hnedzko, D.; Cheruiyot, S.K.; Rozners, E. Using triple-helix-forming peptide nucleic acids for sequence-selective recognition of double-stranded RNA. Curr. Protoc. Nucleic Acid Chem. 2014, 2014, 4-60. [CrossRef]

44. Chakrabarti, M. Thermal stability of PNA/DNA and DNA/DNA duplexes by differential scanning calorimetry. Nucleic Acids Res. 1999, 27, 4801-4806. [CrossRef]

45. Jasiński, M.; Miszkiewicz, J.; Feig, M.; Trylska, J. Thermal stability of peptide nucleic acid complexes. J. Phys. Chem. B 2019, 123, 8168-8177. [CrossRef] [PubMed]

46. Modi, S.; Wani, A.H.; Krishnan, Y. The PNA-DNA hybrid I-motif: Implications for sugar-sugar contacts in I-motif tetramerization. Nucleic Acids Res. 2006, 34, 4354-4363. [CrossRef] [PubMed]

47. Núñez-Pertíñez, S.; Wilks, T.R.; O’Reilly, R.K. Microcalorimetry and fluorescence show stable peptide nucleic acid (PNA) duplexes in high organic content solvent mixtures. Org. Biomol. Chem. 2019, 17, 7874-7877. [CrossRef] [PubMed]

48. Toh, D.F.K.; Patil, K.M.; Chen, G. Sequence-specific and selective recognition of double-stranded RNAs over single-stranded RNAs by chemically modified peptide nucleic acids. J. Vis. Exp. 2017, 2017, e56221. [CrossRef]

49. Devi, G.; Yuan, Z.; Lu, Y.; Zhao, Y.; Chen, G. Incorporation of thio-pseudoisocytosine into triplex-forming peptide nucleic acids for enhanced recognition of RNA duplexes. Nucleic Acids Res. 2014, 42, 4008-4018. [CrossRef] [PubMed]

50. Panecka, J.; Mura, C.; Trylska, J. Molecular dynamics of potential rRNA binders: Single-stranded nucleic acids and some analogues. J. Phys. Chem. B 2011, 115, 532-546. [CrossRef] [PubMed]

51. Sen, S.; Nilsson, L. MD simulations of homomorphous PNA, DNA, and RNA single strands: Characterization and comparison of conformations and dynamics. J. Am. Chem. Soc. 2001, 123, 7414-7422. [CrossRef] [PubMed]

52. Verona, M.D.; Verdolino, V.; Palazzesi, F.; Corradini, R. Focus on PNA Flexibility and RNA Binding using Molecular Dynamics and Metadynamics. Sci. Rep. 2017, 7, 1-11. [CrossRef] [PubMed]

53. Jasiński, M.; Feig, M.; Trylska, J. Improved force fields for peptide nucleic acids with optimized backbone torsion parameters. J. Chem. Theory Comput. 2018, 14, 3603-3620. [CrossRef]

54. Soliva, R.; Sherer, E.; Luque, F.J.; Laughton, C.A.; Orozco, M. Molecular dynamics simulations of PNA.DNA and PNA.RNA duplexes in aqueous solution. J. Am. Chem. Soc. 2000, 122, 5997-6008. [CrossRef]

55. Autiero, I.; Saviano, M.; Langella, E. Molecular dynamics simulations of PNA-PNA and PNA-DNA duplexes by the use of new parameters implemented in the GROMACS package: A conformational and dynamics study. Phys. Chem. Chem. Phys. 2014, 16, 1868-1874. [CrossRef] [PubMed]

56. Corradini, R.; Tedeschi, T.; Sforza, S.; Marchelli, R. Electronic circular dichroism of peptide nucleic acids and their analogues. Compr. Chiroptical Spectrosc. 2012, 2, 587-614. [CrossRef]

57. Pettersen, E.F.; Goddard, T.D.; Huang, C.C.; Couch, G.S.; Greenblatt, D.M.; Meng, E.C.; Ferrin, T.E. UCSF Chimera - A visualization system for exploratory research and analysis. J. Comput. Chem. 2004, 25, 1605-1612. [CrossRef] [PubMed]

58. Sugiyama, T.; Kittaka, A. Chiral peptide nucleic acids with a substituent in the N-(2-Aminoethy) glycine backbone. Molecules 2013, 18, 287-310. [CrossRef]

59. Kirillova, Y.; Boyarskaya, N.; Dezhenkov, A.; Tankevich, M.; Prokhorov, I.; Varizhuk, A.; Eremin, S.; Esipov, D.; Smirnov, I.; Pozmogova, G. Polyanionic carboxyethyl peptide nucleic acids (ce-PNAs): Synthesis and DNA binding. PLOS ONE 2015, 10, 1-19. [CrossRef]

60. Avitabile, C.; Moggio, L.; Malgieri, G.; Capasso, D.; Di Gaetano, S.; Saviano, M.; Pedone, C.; Romanelli, A. $\Gamma$ sulphate PNA (PNA S): Highly selective DNA binding molecule showing promising antigene activity. PLoS ONE 2012, 7, 1-10. [CrossRef]

61. Mitra, R.; Ganesh, K.N. Aminomethylene peptide nucleic acid (am -PNA): Synthesis, regio-/stereospecific DNA binding, and differential cell uptake of $(\alpha / \gamma, \mathrm{R} / \mathrm{S})$ am- PNA analogues. J. Org. Chem. 2012, 77, 5696-5704. [CrossRef]

62. Katritzky, A.R.; Narindoshvili, T. Chiral peptide nucleic acid monomers (PNAM) with modified backbones. Org. Biomol. Chem. 2008, 6, 3171-3176. [CrossRef]

63. Sugiyama, T.; Imamura, Y.; Demizu, Y.; Kurihara, M.; Takano, M.; Kittaka, A. $\beta$-PNA: Peptide nucleic acid (PNA) with a chiral center at the $\beta$-position of the PNA backbone. Bioorganic Med. Chem. Lett. 2011, 21, 7317-7320. [CrossRef] 
64. De Koning, M.C.; Petersen, L.; Weterings, J.J.; Overhand, M.; Van Der Marel, G.A.; Filippov, D.V. Synthesis of thiol-modified peptide nucleic acids designed for post-assembly conjugation reactions. Tetrahedron 2006, 62, 3248-3258. [CrossRef]

65. Sahu, B.; Sacui, I.; Rapireddy, S.; Zanotti, K.J.; Bahal, R.; Armitage, B.A.; Ly, D.H. Synthesis and characterization of conformationally preorganized, (R)-diethylene glycol-containing $\gamma$-peptide nucleic acids with superior hybridization properties and water solubility. J. Org. Chem. 2011, 76, 5614-5627. [CrossRef]

66. Pokorski, J.K.; Witschi, M.A.; Purnell, B.L.; Appella, D.H. (S,S)-trans-cyclopentane-constrained peptide nucleic acids. A general backbone modification that improves binding affinity and sequence specificity. J. Am. Chem. Soc. 2004, 126, 15067-15073. [CrossRef]

67. Govindaraju, T.; Kumar, V.A.; Ganesh, K.N. (SR/RS)-cyclohexanyl PNAs: Conformationally preorganized PNA analogues with unprecedented preference for duplex formation with RNA. J. Am. Chem. Soc. 2005, 127, 4144-4145. [CrossRef] [PubMed]

68. Gangamani, B.P.; Kumar, V.A.; Ganesh, K.N. Synthesis of $N(\alpha)$-(pyrinyl/pyrimidinyl acetyl)-4-aminoproline diastereomers with potential use in PNA synthesis. Tetrahedron 1996, 52, 15017-15030. [CrossRef]

69. Jordan, S.; Schwemler, C.; Kosch, W.; Kretschmer, A.; Stropp, U.; Schwenner, E.; Mielke, B. New hetero-oligomeric peptide nucleic acids with improved binding properties to complementary DNA. Bioorg. Med. Chem. Lett. 1997, 7, 687-690. [CrossRef]

70. Kumar, V.; Pallan, P.S.; Meena; Ganesh, K.N. Pyrrolidine nucleic acids: DNA/PNA oligomers with 2-hydroxy/aminomethyl-4-(thymin-1-yl)pyrrolidine-N-acetic acid. Org. Lett. 2001, 3, 1269-1272. [CrossRef]

71. Worthington, R.J.; O'Rourke, A.P.; Morral, J.; Tan, T.H.S.; Micklefield, J. Mixed-sequence pyrrolidine-amide oligonucleotide mimics: Boc(Z) synthesis and DNA/RNA binding properties. Org. Biomol. Chem. 2007, 5, 249-259. [CrossRef]

72. Ngamwiriyawong, P.; Vilaivan, T. Synthesis and nucleic acids binding properties of diastereomeric aminoethylprolyl peptide nucleic acids (aepPNA). Nucleosides Nucleotides Nucleic Acids 2011, 30, 97-112. [CrossRef]

73. Shirude, P.S.; Kumar, V.A.; Ganesh, K.N. Chimeric peptide nucleic acids incorporating (2S,5R)-aminoethyl pipecolyl units: Synthesis and DNA binding studies. Tetrahedron Lett. 2004, 45, 3085-3088. [CrossRef]

74. Efimov, V.A.; Choob, M.V.; Buryakova, A.A.; Kalinkina, A.L.; Chakhmakhcheva, O.G. Synthesis and evaluation of some properties of chimeric oligomers containing PNA and phosphono-PNA residues. Nucleic Acids Res. 1998, 26, 566-575. [CrossRef]

75. Wojciechowski, F.E.; Hudson, R. Nucleobase modifications in peptide nucleic acids. Curr. Top. Med. Chem. 2007, 7, 667-679. [CrossRef] [PubMed]

76. Hudson, R.H.E.; Heidari, A.; Martin-Chan, T.; Park, G.; Wisner, J.A. On the necessity of nucleobase protection for 2-thiouracil for Fmoc-based pseudo-complementary peptide nucleic acid oligomer synthesis. J. Org. Chem. 2019, 84, 13252-13261. [CrossRef] [PubMed]

77. Ong, A.A.L.; Toh, D.F.K.; Krishna, M.S.; Patil, K.M.; Okamura, K.; Chen, G. Incorporating 2-thiouracil into short double-stranded RNA-binding peptide nucleic acids for enhanced recognition of A-U pairs and for targeting a microRNA hairpin precursor. Biochemistry 2019, 58, 3444-3453. [CrossRef] [PubMed]

78. Neuner, P.; Monaci, P. New Fmoc pseudoisocytosine monomer for the synthesis of a bis-PNA molecule by automated solid-phase Fmoc chemistry. Bioconjug. Chem. 2002, 13, 676-678. [CrossRef]

79. Annoni, C.; Endoh, T.; Hnedzko, D.; Rozners, E.; Sugimoto, N. Triplex-forming peptide nucleic acid modified with 2-aminopyridine as a new tool for detection of A-to-I editing. Chem. Commun. 2016, 52, 7935-7938. [CrossRef]

80. Christensen, L.; Hansen, H.F.; Koch, T.; Nielsen, P.E. Inhibition of PNA triplex formation by N4-benzoylated cytosine. Nucleic Acids Res. 1998, 26, 2735-2739. [CrossRef]

81. Olsen, A.G.; Dahl, O.; Petersen, A.B.; Nielsen, J.N.; Nielsen, P.E. A novel pseudo-complementary PNA G-C base pair. Artif. DNA PNA XNA 2011, 2, 33-37. [CrossRef]

82. Matarazzo, A.; Moustafa, M.E.; Hudson, R.H.E. 5-(Acridin-9-ylamino)uracil-A hydrolytically labile nucleobase modification in peptide nucleic acid. Can. J. Chem. 2013, 91, 1202-1206. [CrossRef]

83. Manicardi, A.; Guidi, L.; Ghidini, A.; Corradini, R. Pyrene-modified PNAs: Stacking interactions and selective excimer emission in PNA2DNA triplexes. Beilstein J. Org. Chem. 2014, 10, 1495-1503. [CrossRef]

84. Zengeya, T.; Gupta, P.; Rozners, E. Triple-helical recognition of RNA using 2-aminopyridine-modified PNA at physiologically relevant conditions. Angew. Chemie Int. Ed. 2012, 51, 12593-12596. [CrossRef] 
85. Manicardi, A.; Gyssels, E.; Corradini, R.; Madder, A. Furan-PNA: A mildly inducible irreversible interstrand crosslinking system targeting single and double stranded DNA. Chem. Commun. 2016, 52, 6930-6933. [CrossRef] [PubMed]

86. Haaima, G. Increased DNA binding and sequence discrimination of PNA oligomers containing 2,6-diaminopurine. Nucleic Acids Res. 1997, 25, 4639-4643. [CrossRef] [PubMed]

87. St. Amant, A.H.; Hudson, R.H.E. Synthesis and oligomerization of Fmoc/Boc-protected PNA monomers of 2,6-diaminopurine, 2-aminopurine and thymine. Org. Biomol. Chem. 2012, 10, 876-881. [CrossRef] [PubMed]

88. Gangamani, B.P.; Kumar, V.A.; Ganesh, K.N. 2-Aminopurine peptide nucleic acids (2-apPNA): Intrinsic fluorescent PNA analogues for probing PNA-DNA interaction dynamics. Chem. Commun. 1997, 1913-1914. [CrossRef]

89. Sanders, J.M.; Wampole, M.E.; Chen, C.P.; Sethi, D.; Singh, A.; Dupradeau, F.Y.; Wang, F.; Gray, B.D.; Thakur, M.L.; Wickstrom, E. Effects of hypoxanthine substitution in peptide nucleic acids targeting KRAS2 oncogenic mRNA molecules: Theory and experiment. J. Phys. Chem. B 2013, 117, 11584-11595. [CrossRef] [PubMed]

90. Vilaivan, C.; Srinarang, W.; Yotapan, N.; Mansawat, W.; Boonlua, C.; Kawakami, J.; Yamaguchi, Y.; Tanaka, Y.; Vilaivan, T. Specific recognition of cytosine by hypoxanthine in pyrrolidinyl peptide nucleic acid. Org. Biomol. Chem. 2013, 11, 2310-2317. [CrossRef]

91. Hansen, H.F.; Christensen, L.; Dahl, O.; Nielsen, P.E. 6-thioguanine in peptide nucleic acids. Synthesis and hybridization properties. Nucleosides Nucleotides 1999, 18, 5-9. [CrossRef]

92. Kotikam, V.; Kennedy, S.D.; MacKay, J.A.; Rozners, E. Synthetic, structural, and RNA binding studies on 2-aminopyridine-modified triplex-forming peptide nucleic acids. Chem. A Eur. J. 2019, 25, 4367-4372. [CrossRef]

93. Tähtinen, V.; Verhassel, A.; Tuomela, J.; Virta, P. $\gamma-(S)$-Guanidinylmethyl-modified triplex-forming peptide nucleic acids increase hoogsteen-face affinity for a microRNA and enhance cellular uptake. ChemBioChem 2019, 20, 3041-3051. [CrossRef]

94. Eldrup, A.B.; Christensen, C.; Haaima, G.; Nielsen, P.E. Substituted 1,8-naphthyridin-2(1H)-ones are superior to thymine in the recognition of adenine in duplex as well as triplex structures. J. Am. Chem. Soc. 2002, 124, 3254-3262. [CrossRef]

95. Rajeev, K.G.; Maier, M.A.; Lesnik, E.A.; Manoharan, M. High-affinity peptide nucleic acid oligomers containing tricyclic cytosine analogues. Org. Lett. 2002, 4, 4395-4398. [CrossRef] [PubMed]

96. Ortega, J.A.; Blas, J.R.; Orozco, M.; Grandas, A.; Pedroso, E.; Robles, J. Binding affinities of oligonucleotides and PNAs containing phenoxazine and G-clamp cytosine analogues are unusually sequence-dependent. Org. Lett. 2007, 9, 4503-4506. [CrossRef] [PubMed]

97. Köhler, O.; Jarikote, D.V.; Seitz, O. Forced intercalation probes (FIT Probes): Thiazole orange as a fluorescent base in peptide nucleic acids for homogeneous single-nucleotide-polymorphism detection. ChemBioChem 2005, 6, 69-77. [CrossRef] [PubMed]

98. Wojciechowski, F.; Hudson, R.H.E. Peptide nucleic acid containing a meta-substituted phenylpyrrolocytosine exhibits a fluorescence response and increased binding affinity toward RNA. Org. Lett. 2009, 11, 4878-4881. [CrossRef]

99. Frey, K.A.; Woski, S.A. Fluoroaromatic universal bases in peptide nucleic acids. Chem. Commun. 2002, 2, 2206-2207. [CrossRef]

100. Sanjayan, G.J.; Pedireddi, V.R.; Ganesh, K.N. Cyanuryl-PNA monomer: Synthesis and crystal structure. Org. Lett. 2000, 2, 2825-2828. [CrossRef]

101. Nölling, J.; Rapireddy, S.; Amburg, J.I.; Crawford, E.M.; Prakash, R.A.; Rabson, A.R.; Tang, Y.W.; Singer, A. Duplex DNA-invading $\gamma$-modified peptide nucleic acids enable rapid identification of bloodstream infections in whole blood. MBio 2016, 7,1-11. [CrossRef]

102. Good, L.; Sandberg, R.; Larsson, O.; Nielsen, P.E.; Wahlestedt, C. Antisense PNA effects in Escherichia coli are limited by the outer-membrane LPS layer. Microbiology 2000, 146, 2665-2670. [CrossRef]

103. Zanardi, C.; Terzi, F.; Seeber, R.; Baldoli, C.; Licandro, E.; Maiorana, S. Peptide Nucleic Acids tagged with four lysine residues for amperometric genosensors. Artif. DNA PNA XNA 2012, 3, 1-8. [CrossRef]

104. Totsingan, F.; Jain, V.; Bracken, W.C.; Faccini, A.; Tedeschi, T.; Marchelli, R.; Corradini, R.; Kallenbach, N.R.; Green, M.M. Conformational heterogeneity in PNA:PNA duplexes. Macromolecules 2010, 43, 2692-2703. [CrossRef] 
105. Barkowsky, G.; Lemster, A.L.; Pappesch, R.; Jacob, A.; Krüger, S.; Schröder, A.; Kreikemeyer, B.; Patenge, N. Influence of different cell-penetrating peptides on the antimicrobial efficiency of PNAs in Streptococcus pyogenes. Mol. Ther. Nucleic Acids 2019, 18, 444-454. [CrossRef] [PubMed]

106. Morris, M.C.; Gros, E.; Aldrian-Herrada, G.; Choob, M.; Archdeacon, J.; Heitz, F.; Divita, G. A non-covalent peptide-based carrier for in vivo delivery of DNA mimics. Nucleic Acids Res. 2007, 35, e49. [CrossRef] [PubMed]

107. Vaara, M.; Porro, M. Group of peptides that act synergistically with hydrophobic antibiotics against gram-negative enteric bacteria. Antimicrob. Agents Chemother. 1996, 40, 1801-1805. [CrossRef] [PubMed]

108. Bai, H.; Sang, G.; You, Y.; Xue, X.; Zhou, Y.; Hou, Z.; Meng, J.; Luo, X. Targeting RNA polymerase primary $\sigma$ 70 as a therapeutic strategy against methicillin-resistant Staphylococcus aureus by antisense peptide nucleic acid. PLoS ONE 2012, 7, e29886. [CrossRef]

109. Bendifallah, N.; Rasmussen, F.W.; Zachar, V.; Ebbesen, P.; Nielsen, P.E.; Koppelhus, U. Evaluation of cell-penetrating peptides (CPPs) as vehicles for intracellular delivery of antisense peptide nucleic acid (PNA). Bioconjug. Chem. 2006, 17, 750-758. [CrossRef]

110. Bai, H.; You, Y.; Yan, H.; Meng, J.; Xue, X.; Hou, Z.; Zhou, Y.; Ma, X.; Sang, G.; Luo, X. Antisense inhibition of gene expression and growth in gram-negative bacteria by cell-penetrating peptide conjugates of peptide nucleic acids targeted to rpoD gene. Biomaterials 2012, 33, 659-667. [CrossRef]

111. Patenge, N.; Pappesch, R.; Krawack, F.; Walda, C.; Mraheil, M.A.; Jacob, A.; Hain, T.; Kreikemeyer, B. Inhibition of growth and gene expression by PNA-peptide conjugates in Streptococcus pyogenes. Mol. Ther. Nucleic Acids 2013, 2, e132. [CrossRef]

112. Abushahba, M.F.N.; Mohammad, H.; Thangamani, S.; Hussein, A.A.A.; Seleem, M.N. Impact of different cell penetrating peptides on the efficacy of antisense therapeutics for targeting intracellular pathogens. Sci. Rep. 2016, 6, 1-12. [CrossRef]

113. Joshi, S.; Bisht, G.S.; Rawat, D.S.; Kumar, A.; Kumar, R.; Maiti, S.; Pasha, S. Interaction studies of novel cell selective antimicrobial peptides with model membranes and E. coli ATCC 11775. Biochim. Biophys. Acta Biomembr. 2010, 1798, 1864-1875. [CrossRef]

114. Ghosal, A.; Vitali, A.; Stach, J.E.M.; Nielsen, P.E. Role of SbmA in the uptake of peptide nucleic acid (PNA)-peptide conjugates in E. coli. ACS Chem. Biol. 2013, 8, 360-367. [CrossRef]

115. Hansen, A.M.; Bonke, G.; Larsen, C.J.; Yavari, N.; Nielsen, P.E.; Franzyk, H. Antibacterial peptide nucleic acid-antimicrobial peptide (PNA-AMP) conjugates: Antisense targeting of fatty acid biosynthesis. Bioconjug. Chem. 2016, 27, 863-867. [CrossRef] [PubMed]

116. Goltermann, L.; Yavari, N.; Zhang, M.; Ghosal, A.; Nielsen, P.E. PNA length restriction of antibacterial activity of peptide-PNA conjugates in Escherichia coli through effects of the inner membrane. Front. Microbiol. 2019, 10, 1-8. [CrossRef] [PubMed]

117. Turner, J.J.; Ivanova, G.D.; Verbeure, B.; Williams, D.; Arzumanov, A.A.; Abes, S.; Lebleu, B.; Gait, M.J. Cell-penetrating peptide conjugates of peptide nucleic acids (PNA) as inhibitors of HIV-1 Tat-dependent trans-activation in cells. Nucleic Acids Res. 2005, 33, 6837-6849. [CrossRef] [PubMed]

118. Zaro, J.L.; Shen, W.C. Cationic and amphipathic cell-penetrating peptides (CPPs): Their structures and in vivo studies in drug delivery. Front. Chem. Sci. Eng. 2015, 9, 407-427. [CrossRef]

119. Równicki, M.; Wojciechowska, M.; Wierzba, A.J.; Czarnecki, J.; Bartosik, D.; Gryko, D.; Trylska, J. Vitamin B12 as a carrier of peptide nucleic acid (PNA) into bacterial cells. Sci. Rep. 2017, 7, 7644. [CrossRef]

120. Cordier, C.; Boutimah, F.; Bourdeloux, M.; Dupuy, F.; Met, E.; Alberti, P.; Loll, F.; Chassaing, G.; Burlina, F.; Saison-Behmoaras, T.E. Delivery of antisense peptide nucleic acids to cells by conjugation with small arginine-rich cell-penetrating peptide (R/W)9. PLoS ONE 2014, 9, e104999. [CrossRef]

121. Järver, P.; Coursindel, T.; El Andaloussi, S.; Godfrey, C.; Wood, M.J.; Gait, M.J. Peptide-mediated cell and in vivo delivery of antisense oligonucleotides and siRNA. Mol. Ther. Nucleic Acids 2012, 1, e27. [CrossRef]

122. Nekhotiaeva, N.; Awasthi, S.K.; Nielsen, P.E.; Good, L. Inhibition of Staphylococcus aureus gene expression and growth using antisense peptide nucleic acids. Mol. Ther. 2004, 10, 652-659. [CrossRef]

123. Giannella, R.A.; Broitman, S.A.; Zamcheck, N. Vitamin B12 uptake by intestinal microorganisms: Mechanism and relevance to syndromes of intestinal bacterial overgrowth. J. Clin. Investig. 1971, 50, 1100-1107. [CrossRef] 
124. Pieńko, T.; Wierzba, A.J.; Wojciechowska, M.; Gryko, D.; Trylska, J. Conformational dynamics of cyanocobalamin and its conjugates with peptide nucleic acids. J. Phys. Chem. B 2017, 121, 2968-2979. [CrossRef] [PubMed]

125. Wierzba, A.J.; Maximova, K.; Wincenciuk, A.; Równicki, M.; Wojciechowska, M.; Nexø, E.; Trylska, J.; Gryko, D. Does a conjugation site affect transport of vitamin B12-peptide nucleic acid conjugates into bacterial cells? Chem. A Eur. J. 2018, 24, 18772-18778. [CrossRef] [PubMed]

126. Readman, J.B.; Dickson, G.; Coldham, N.G. Tetrahedral DNA nanoparticle vector for intracellular delivery of targeted peptide nucleic acid antisense agents to restore antibiotic sensitivity in cefotaxime-resistant Escherichia coli. Nucleic Acid Ther. 2017, 27, 176-181. [CrossRef] [PubMed]

127. Zhang, Y.; Ma, W.; Zhu, Y.; Shi, S.; Li, Q.; Mao, C.; Zhao, D.; Zhan, Y.; Shi, J.; Li, W.; et al. Inhibiting methicillin-resistant Staphylococcus aureus by tetrahedral DNA nanostructure-enabled antisense peptide nucleic acid delivery. Nano Lett. 2018, 18, 5652-5659. [CrossRef] [PubMed]

128. Rajasekaran, P.; Alexander, J.C.; Seleem, M.N.; Jain, N.; Sriranganathan, N.; Wattam, A.R.; Setubal, J.C.; Boyle, S.M. Peptide nucleic acids inhibit growth of Brucella suis in pure culture and in infected murine macrophages. Int. J. Antimicrob. Agents 2013, 41, 358-362. [CrossRef]

129. Otsuka, T.; Brauer, A.L.; Kirkham, C.; Sully, E.K.; Pettigrew, M.M.; Kong, Y.; Geller, B.L.; Murphy, T.F. Antimicrobial activity of antisense peptide-peptide nucleic acid conjugates against non-typeable Haemophilus influenzae in planktonic and biofilm forms. J. Antimicrob. Chemother. 2017, 72, 137-144. [CrossRef]

130. Ghosal, A.; Nielsen, P.E. Potent antibacterial antisense peptide-peptide nucleic acid conjugates against pseudomonas aeruginosa. Nucleic Acid Ther. 2012, 22, 323-334. [CrossRef]

131. Dryselius, R.; Nekhotiaeva, N.; Good, L. Antimicrobial synergy between mRNA- and protein-level inhibitors. J. Antimicrob. Chemother. 2005, 56, 97-103. [CrossRef]

132. Castillo, J.I.; Równicki, M.; Wojciechowska, M.; Trylska, J. Antimicrobial synergy between mRNA targeted peptide nucleic acid and antibiotics in E. coli. Bioorganic Med. Chem. Lett. 2018, 28, 3094-3098. [CrossRef]

133. Kulyté, A.; Nekhotiaeva, N.; Awasthi, S.K.; Good, L. Inhibition of Mycobacterium smegmatis gene expression and growth using antisense peptide nucleic acids. J. Mol. Microbiol. Biotechnol. 2005, 9, 101-109. [CrossRef]

134. Mondhe, M.; Chessher, A.; Goh, S.; Good, L.; Stach, J.E.M. Species-selective killing of bacteria by antimicrobial Peptide-PNAs. PLoS ONE 2014, 9, 1-8. [CrossRef]

135. Tan, X.X.; Actor, J.K.; Chen, Y. Peptide nucleic acid antisense oligomer as a therapeutic strategy against bacterial infection: Proof of principle using mouse intraperitoneal infection. Antimicrob. Agents Chemother. 2005, 49, 3203-3207. [CrossRef] [PubMed]

136. Trylska, J.; Thoduka, S.G.; Dabrowska, Z. Using sequence-specific oligonucleotides to inhibit bacterial rRNA. ACS Chem. Biol. 2013, 8, 1101-1109. [CrossRef] [PubMed]

137. Good, L.; Nielsen, P.E. Inhibition of translation and bacterial growth by peptide nucleic acid targeted to ribosomal RNA. Proc. Natl. Acad. Sci. USA 1998, 95, 2073-2076. [CrossRef] [PubMed]

138. Shi, X.; Khade, P.K.; Sanbonmatsu, K.Y.; Joseph, S. Functional role of the sarcin-ricin loop of the 23s rRNA in the elongation cycle of protein synthesis. J. Mol. Biol. 2012, 419, 125-138. [CrossRef]

139. Kulik, M.; Markowska-Zagrajek, A.; Wojciechowska, M.; Grzela, R.; Wituła, T.; Trylska, J. Helix 69 of Escherichia coli 23S ribosomal RNA as a peptide nucleic acid target. Biochimie 2017, 138, 32-42. [CrossRef]

140. Hatamoto, M.; Nakai, K.; Ohashi, A.; Imachi, H. Sequence-specific bacterial growth inhibition by peptide nucleic acid targeted to the mRNA binding site of 16S rRNA. Appl. Microbiol. Biotechnol. 2009, 84, 1161-1168. [CrossRef]

141. Rasmussen, L.C.V.; Sperling-Petersen, H.U.; Mortensen, K.K. Hitting bacteria at the heart of the central dogma: Sequence-specific inhibition. Microb. Cell Fact. 2007, 6, 1-26. [CrossRef]

142. Górska, A.; Markowska-Zagrajek, A.; Równicki, M.; Trylska, J. Scanning of $16 \mathrm{~S}$ ribosomal RNA for peptide nucleic acid targets. J. Phys. Chem. B 2016, 120, 8369-8378. [CrossRef]

143. Hu, J.; Xia, Y.; Xiong, Y.; Li, X.; Su, X. Inhibition of biofilm formation by the antisense peptide nucleic acids targeted at the motA gene in Pseudomonas aeruginosa PAO1 strain. World J. Microbiol. Biotechnol. 2011, 27, 1981-1987. [CrossRef]

144. Narenji, H.; Teymournejad, O.; Rezaee, M.A.; Taghizadeh, S.; Mehramuz, B.; Aghazadeh, M.; Asgharzadeh, M.; Madhi, M.; Gholizadeh, P.; Ganbarov, K.; et al. Antisense peptide nucleic acids againstftsZ andefaA genes inhibit growth and biofilm formation of Enterococcus faecalis. Microb. Pathog. 2020, 139, 103907. [CrossRef] 
145. Jeon, B.; Zhang, Q. Sensitization of Campylobacter jejuni to fluoroquinolone and macrolide antibiotics by antisense inhibition of the CmeABC multidrug efflux transporter. J. Antimicrob. Chemother. 2009, 63, 946-948. [CrossRef] [PubMed]

146. Równicki, M.; Pieńko, T.; Czarnecki, J.; Kolanowska, M.; Bartosik, D.; Trylska, J. Artificial activation of Escherichia coli mazEF and hipBA toxin-antitoxin systems by antisense peptide nucleic acids as an antibacterial strategy. Front. Microbiol. 2018, 9, 1-13. [CrossRef] [PubMed]

147. Wang, H.; He, Y.; Xia, Y.; Wang, L.; Liang, S. Inhibition of gene expression and growth of multidrug-resistant Acinetobacter baumannii by antisense peptide nucleic acids. Mol. Biol. Rep. 2014, 41, 7535-7541. [CrossRef] [PubMed]

148. Kurupati, P.; Tan, K.S.W.; Kumarasinghe, G.; Poh, C.L. Inhibition of gene expression and growth by antisense peptide nucleic acids in a multiresistant $\beta$-lactamase-producing Klebsiella pneumoniae strain. Antimicrob. Agents Chemother. 2007, 51, 805-811. [CrossRef] [PubMed]

149. Soofi, M.A.; Seleem, M.N. Targeting essential genes in Salmonella enterica serovar typhimurium with antisense peptide nucleic acid. Antimicrob. Agents Chemother. 2012, 56, 6407-6409. [CrossRef]

150. Belete, T.M. Novel targets to develop new antibacterial agents and novel alternatives to antibacterial agents. Hum. Microbiome J. 2019, 11, 100052. [CrossRef]

151. Monserrat-Martinez, A.; Gambin, Y.; Sierecki, E. Thinking outside the bug: Molecular targets and strategies to overcome antibiotic resistance. Int. J. Mol. Sci. 2019, 20, 1255. [CrossRef]

152. Stein, C.A.; Castanotto, D. FDA-approved oligonucleotide therapies in 2017. Mol. Ther. 2017, 25, $1069-1075$. [CrossRef]

153. Wu, J.C.; Meng, Q.C.; Ren, H.M.; Wang, H.T.; Wu, J.; Wang, Q. Recent advances in peptide nucleic acid for cancer bionanotechnology. Acta Pharmacol. Sin. 2017, 38, 798-805. [CrossRef]

154. Quijano, E.; Bahal, R.; Ricciardi, A.; Saltzman, W.M.; Glazer, P.M. Therapeutic peptide nucleic acids: Principles, limitations, and opportunities. Yale J. Biol. Med. 2017, 90, 583-598.

155. Malic, S.; Hill, K.E.; Hayes, A.; Percival, S.L.; Thomas, D.W.; Williams, D.W. Detection and identification of specific bacteria in wound biofilms using peptide nucleic acid fluorescent in situ hybridization (PNA FISH). Microbiology 2009, 155, 2603-2611. [CrossRef] [PubMed]

156. Mach, K.E.; Kaushik, A.M.; Hsieh, K.; Wong, P.K.; Wang, T.H.; Liao, J.C. Optimizing peptide nucleic acid probes for hybridization-based detection and identification of bacterial pathogens. Analyst 2019, 144, 1565-1574. [CrossRef] [PubMed]

157. Gomez, A.; Miller, N.S.; Smolina, I. Visual detection of bacterial pathogens via PNA-based padlock probe assembly and isothermal amplification of DNAzymes. Anal. Chem. 2014, 86, 11992-11998. [CrossRef] [PubMed]

(C) 2020 by the authors. Licensee MDPI, Basel, Switzerland. This article is an open access article distributed under the terms and conditions of the Creative Commons Attribution (CC BY) license (http://creativecommons.org/licenses/by/4.0/). 